\title{
Empathy in Rudyard Kipling's Jungle Books, Mirrored in Illustrations by John Lockwood Kipling and Aldren Watson
}

\author{
Norman Arthur Fischer \\ Kent State University (Retired), Kent, Ohio, USA
}

\begin{abstract}
Rudyard Kipling's Jungle Books depict empathy in the animal and animal-human world, and the illustrations of Rudyard's father, John Lockwood Kipling, and the American artist and prolific illustrator, Aldren Watson, help depict that empathy. Lockwood Kipling was both influence on and interpreter of the Jungle Books, as shown above all in the development from his Beast and Man in India of 1891 through his illustrations for the 1894 Jungle Book, and 1895 Second Jungle Book, to his illustrations that appear in the rearranged stories of The Jungle Book, and Second Jungle Book in the 1897 Scribners Outward Bound (O/B) editions. A variation on Lockwood's O/B mode of Jungle Books illustrations is found in Watson's illustrations for the 1948 Doubleday edition, Jungle Books, which is the title I will use throughout. ${ }^{1}$

Part One details the influence of two animal empathy writers, Lockwood Kipling and Ernest Thompson Seton, on the Jungle Books. Part Two uses recent philosophical studies of empathy in the animal and human relationship. Part Three applies a German philosophy of art history to the new look of the O/B and Doubleday Jungle Books. Part Four interprets selected Jungle Books stories in the light of Parts one, two and three.
\end{abstract}

Keywords: Jungle Books, Rudyard Kipling, John Lockwood Kipling, Arne Naess, Ernest Thompson Seton, Aldren Watson, Wilhelm Worringer, empathy for animals, expressionism

\section{Part One: Animal Empathy Influences}

The first written work that sheds light on empathy in the animal-human relation in the Jungle Books is Lockwood's Beast and Man in India (1891). This book is a revelation for understanding the Jungle Books. Very early Lockwood established his allegiance to the burgeoning humane society movement, when he praises the Indian parliament for passing Humane Society type legislation. ${ }^{2}$ This theme runs throughout Beast and Man in India, and is buttressed by subthemes, in the way that the main water body of a watershed is fed by its smaller bodies of water. $^{3}$

Norman Arthur Fischer, Professor of Philosophy, Kent State University (Retired), Kent, Ohio, USA. parsquix@aol.com.

${ }^{1}$ Rudyard Kipling, The Jungle Book (London: Macmillan, 1894); The Second Jungle Book (London: Macmillan, 1895). The Jungle Book, Volume VII; The Second Jungle Book, Volume VIII, of The Writings in Prose and Verse of Rudyard Kipling (New York: Charles Scribners Sons, 1897). Rudyard Kipling.,The Jungle Books, Volumes One and Two, illustrated by by Aldren Watson, "Forward" by Nelson Doubleday (New York: Doubleday, 1948). John Lockwood Kipling, Beast and Man in India (London: Macmillian, 1904).

${ }^{2}$ John Lockwood Kipling, Beast and Man in India, 1-4.

${ }^{3}$ Ibid., 170, 172, 199, 202, 204, 206-208, 220, 249, 252-253, 255, 283-287. 
The second great animal empathy influence on the Jungle Books is the animal narratives of Ernest Thompson Seton. Seton's work had begun to appear in North America, under the name of Ernest Seton Thompson, shortly before Rudyard composed the1894 Jungle Book and 1895 Second Jungle Book in Brattleboro, Vermont. Seton received a letter from Rudyard stating that at least two of Seton's animal stories had influenced his composition of what Seton called Jungle Tales: "Kipling wrote in a letter now before me that he had read 'Silverspot' and 'Molly Cottontail' (1890) in the St. Nicholas, and had been greatly influenced by them before writing his Jungle Tales, 1895."

In November, 1894 Seton published "The King of Currumpaw, a Wolf Story," in Scribners Magazine. In 1898, in Wild Animals I Have Known, Seton republished that story as "Lobo The King of Currumpaw," along with the two stories that Kipling told Seton had greatly influenced the Jungle Books. The crow, Silverspot, is indeed the Wild animal Silverspot that Seton knew and described in "Silverspot, the Story of a Crow." But Molly Cottontail is actually the mother of the wild animal Raggylug Seton knew and described in "Raggylug, the Story of a Cottontail Rabbit.” Molly is as central to the story as Raggylug, if not more central, so we can be sure that "Raggylug" is the story Rudyard read. ${ }^{5}$ It is also highly likely, given its original appearance in November, 1894, that Rudyard read the story of Lobo.

It was not until 1898 that Seton declared "Since, then, the animals are creatures with wants and feelings differing in degree only from our own, they surely have their rights." "Silverspot" appeared second in that volume, just after "Lobo, the King of Currumpaw," and just before "Raggylug," which was followed, after two more stories, by "The Pacing Mustang." Seton's animal rights declaration is rather general, but the May 2010-May 2011 exhibit of Seton's work in Santa Fe has shed light on the relation between "Lobo," "The Pacing Mustang," and animal rights, and by inference between the two stories we are sure Kipling read, "Silverspot” and "Raggylug," and animal rights. The exhibit establishes that the human exploitation of wild animals that Seton observed and even engaged in in New Mexico, between late 1893 and early 1894, and that resulted in the writing of "Lobo" and "The Pacing Mustang," also caused a conversion on Seton's part to even greater empathy for animals than he had already developed in his life in and around Toronto, the scene of "Silverspot." ${ }^{8}$ Until further proof shows up, however, that Kipling read these New Mexico based stories, I must rely primarily on Rudyard's self declared use of "Silverspot" and "Raggylug" in the Jungle Books, to back up the thematic similarities between Seton's and Rudyard's defense of the wild and condemnation of human exploitation of wild animals.

When the Jungle Books characterize empathy in the context of the social world of India, they are very close to that world as chronicled by Lockwood and his conception of animal life within the social context of India. The resulting stories are unlike the purely natural world of Silverspot and also unlike the world of Raggylug, Lobo and the Pacing mustang, where the natural life of the wild rabbit, wolf and horse is destroyed by humans, and

\footnotetext{
${ }^{4}$ Ernest Thompson Seton, The Trail of an Artist-Naturalist (New York. Charles Scribners Sons, 1940), 353.

${ }^{5}$ Ernest Seton Thompson, "The King of Currumpaw, A Wolf Story,” Scribner's Magazine, November, 1894; "Lobo The King of Currumpaw." "Silverspot, the Story of a Crow"; "Raggylug, the Story of a Cottontail Rabbit," in Wild Animals I Have Known (New York: Charles Scribners Sons, 1898).

${ }^{6}$ Seton Thompson, “Note to the Reader,” in Wild Animals I Have Known, 12.

${ }^{7}$ Seton Thompson, "The Pacing Mustang," in Wild Animals I Have Known.

${ }^{8}$ David L. Witt, Ernest Thompson Seton: The Life and Legacy of an Artist and Conservationist. (Salt Lake City Gibbs Smith, 2010), Catalogue and exhibition by the Academy for the Love of Learning, in conjunction with the New Mexico Historical Museum, Santa Fe, May 2010 through May 2011, 5, 9-10, 34-36.
} 
reflect Seton's critique of society's impingement on the animal world. Other stories reflect both influences. Thus, if I am correct, the dual influence of Lockwood and Seton helps structure the animal empathy themes of the Jungle Books, and earlier accounts that treat these influences as peripheral or do not treat them at all, must be corrected.

\section{Part Two: Philosophical Approaches to Empathy in the Animal and Animal-Human World}

Part Two uses new philosophical studies of empathy in the animal and animal-human world. This is where the late Norwegian environmental philosopher, Arne Naess' subjective nature philosophy can help us appreciate the theme of empathy in the animal human relation in the Jungle Books. Often when Rudyard is writing at his best about animals, it is primarily to express a subjective emotional state or to create an imaginary world, far removed, in crucial respects, from actual animals. For the deeply expressive and imaginative elements in Rudyard's, Lockwood's and Watson's art, Naess' subjective concept of empathic identification with nature and animals fits in well. Naess embraced a concept of an empathic self achieving identification with nature and animals, and utilizing subjective expression and imagination.

The self that empathically identifies with nature and animals, and particularly Naess' strongly subjective version of such identification fits in with the Kiplings' and Watson's depiction of empathy in the animal-human relation.

Naess has written movingly about the empathic self, all under the rubric of the self's acquisition of an "ecosophy" i.e., a system of wisdom about nature and animals. For Naess, there are many such ecosophies; Naess' own "ecosophy T" turns the self away from too much emphasis on the ego cut off from nature and animals. In ecosophy $\mathrm{T}$ health comes to the self when it comes to understand its need for such empathic identification with nature and animals. ${ }^{9}$ I cannot attribute such an ecosophy in any direct sense to either the Kiplings or Watson. But the depth of their depictions of empathic identification resonates well with Naess's theory.

Naess' own ecosophy $\mathrm{T}$ involves in its broadest meaning a transcendental leap to empathic identification with a larger whole, such as nature, the animal world, or human society, and must always locate itself specifically with specific animals or species or ecosystem in nature, or community within human society. In its narrower sense the identification is with animals, and the narrower interpretation is obviously the more crucial for Rudyard's Jungle Books, and their mirroring in Lockwood's and Watson's illustrations. Naess' prime relevance for empathy in the Jungle Books comes not just from ecosophy T, but also from Naess' thoughts when he had to consider the possibility of an existential ecosoophy, very different from ecosopy $\mathrm{T}$, and one that in many ways fits Rudyard's, Lockwood's and Watson's Jungle Books better than Naess's own ecosophy T.

Ecosophy $\mathrm{T}$ is firmly transcendental in its approach to empathic identification. It demands ability to transcend the limited self and identify with a larger world, at least part of which is not just larger than, but also transcends, the ego. Philosophical interrogation of ecosophy $\mathrm{T}$ and ecosophies in general, demands that a hard question be posed for Naess. Isn’t there a difference between actually achieving empathic identification with nature and the animal world and simply probing the possibility of such identification? This distinction concerns

\footnotetext{
${ }^{9}$ Arne Naess, “The Deep Ecology Movement Some Philosophical Aspects;” "Self-realization,” in Deep Ecology for the 21st Century, ed. George Sessions (New York: Shambala, 1995), 79-83; "Identification as a source for Deep Ecological Attitudes,” in Deep Ecology, ed. Michael Tobias (San Diego: Avanti Books, 1985), 258-264.
} 
the degree of empathic identification with the natural and animal world that the self needs, or can attain. For Naess' own ecosophy T, self-realization can occur only through actual transcendental and empathic identification with nature and the animal world. Such strong identification with nature results in a "wider self." ${ }^{10}$ Naess always, of course, emphasized that there were ecosophhies other than his T, but it did seem until 1990 that all of them, although particularly $\mathrm{T}$, demanded some actual empathic identification with nature or the animal world. But is such an actual empathic identification a common feature of all ecosophies? Naess' ecosophy T is, after all, only an example of an ecosophy. Rudyard's, Lockwood's and Watson's Jungle Books do not rest on an intuition of such actual empathic identification, but fit in much better with a more troubled model, of posing the question of empathic identification, without necessarily achieving it. This probing may or may not use transcendental motifs, and even if it does it may or may not accept their validity. This troubled and probing model of empathic identification would be more existential.

It did seem until 1990, on the basis of most of Naess' writings and examples until then, that all ecosophies involved actual empathic identification with some larger aspect of nature or the animal world, and that ecosophy T was special because the identification was transcendental. However, in responding in that year to Peter Reed's 1989 claim that an ecosophy could be derived from what amounted to failed empathy, arising out of humanity's existential sense of separateness from nature and the animal world, Naess seemed to agree that this is possible. ${ }^{11}$ This makes problematic the logical link between being an ecosophy and stressing expansion of the self's actual ability to empathically identify with nature and the animal world. I would like to therefore suggest that, in a primary sense, an ecosophy either expands the self's ability to empathically identify with nature and the animal world, whether this be through transcendental means, as in Naess' ecosophy $\mathrm{T}$, or not, or regards such expansion of empathic identification as possible. However, in a secondary sense, simply by posing the question of whether there is greater or lesser possibility of the self empathically identifying with nature and the animal world, through transcendental or some other means, an ecosophy can emerge. ${ }^{12}$

One clue to the aesthetic meaning of the two types of identification is that Reed's idea was based in part on writings by another Norwegian environmental philosopher, Peter Wessel Zapffe, who was an existentialist. ${ }^{13}$ Zapffe was obviously a very different kind of nature and animal philosopher than his friend Naess. Naess always remained optimistic about the possibility of achieving empathic identification with a transcendent larger whole. Whereas Naess originally, throughout most of the nineteen seventies, defined environmental probing in terms of the depth of the question asked about the objective aspect of nature and the animal world, increasingly in the nineteen eighties and nineties he defined it in terms of the depth of wisdom about the earth that allowed empathic identification with nature and animals. Reed, building on Zapffe, developed a similar concept. But whereas the Naessian deep environmental self actually achieves empathic identification with nature and the animal world, the Reed-Zapffe deep environmental self raises severe doubts about whether such empathic identification is possible.

\footnotetext{
${ }^{10}$ Arne Naess, “Deepness of Questions and the Deep Ecology Movement;" “The Place of Joy in a World of Facts,” in Deep Ecology for the 21st Century, 221, 257.

${ }^{11}$ Peter Reed. "Not Man Apart: An Alternative to the Self-realization Approach,” Environmental Ethics, 1989 Volume 11, No. 1, 53-69; Arne Naess, "Man Apart and Deep Ecology: A Reply to Reed,” Environmental Ethics, 1990, Volume 12, No. 2, $190-191$.

${ }^{12}$ Arne Naes, "Self-realization,” 233; “Identification,” 259-260.

13 Peter Wessell Zapfe, “THE Last Messiah,” in Peter Reed and David Rothenberg, ed. Wisom in the Open Air (Minneapolis: Univerity of Mennesota Press, 1993).
} 
The distinction between the two attitudes toward empathic identification can illuminate Rudyard's, Lockwood's, and Watson's Jungle Books.

\section{Part Three: The New Look of the Jungle Books Both in Lockwood's Illustrations for the O/B Editions and in Watson's Illustrations for the O/B Based 1948 Doubleday Edition}

Part Three uses German aesthetics and philosophy of art history to shed light on the illustrations for the O/B and 1948 Doubleday editions. Rudyard described the O/B edition In Volume I, Plain Tale From the Hills, and the physical nature of Lockwood's illustrations—photographs of clay models—is also described there. ${ }^{14}$

The thirty six volumes of the first Scribners O/B edition appeared between 1897 and 1937. Between 1897 and 1903 Lockwood illustrated seventeen of the first twenty one volumes of $\mathrm{O} / \mathrm{B}$, each one containing three illustrations, with the exception of the ten illustrations for Volume XIX. Kim, making a total of fifty eight.

All fifty eight illustrations possess a unifying style, based partly on their physical mode of composition—photographs of clay models—but also on a new approach to the visual form of the artworks. The three illustrations for the O/B Jungle Book and three for the O/B Second Jungle Book are very much in tune with this new visual form, and thus must be seen as part of a unifying vision of the O/B edition, and also as a departure from the visual form of Lockwood's 1894/5 illustrations. The 1894/5 illustrations can be analyzed almost completely in terms of what art historians have called the classic form, although some can be analyzed in terms of what they have called the romantic form. The fifty eight O/B Illustrations, including the six for the Jungle Books, hardly ever follow the classic form. Instead they follow either the romantic form, or the expressionist form, above all as that form was elucidated by aestheticians Wilhelm Worringer and Herbert Read; or they follow what I will call the romantic epressionist form. In using the term expressionism, however, I am not confining myself to the art movement most associated with that name as it flourished outside of the Paris art world, particularly in Germany and countries close to Germany in the later nineteenth and early twentieth centuries.

Rather than appealing to art historians who explicitly contrast classicism and romanticism, I will begin with an art historian cited by Worringer, Heinrich Wolfflin, and his basic contrast between painting that is 1 based on lines; 2 gives a sense of sticking to the plane and not going into the interior; with 3 a sense of enclosure within the picture; 4 gives a sense of unity; and 5 clarity. In fact when later art historians talk about the classic it tends to be this form. When they talk about the romantic form they tend to follow Wolfflin’s opposite categories: painting that 1 is not based on line; 2 moves from the plane to the interior; 3 does not accept the enclosed frame, but moves outward; 4 is less unified; and 5 less clear. ${ }^{15}$ Only some of Lockwood's 1894/95 Jungle Books illustrations are romantic, whereas most of his $\mathrm{O} / \mathrm{B}$ Jungle Books illustrations and many of his other fifty two O/B illustrations are romantic. However, some of those O/B Jungle Books illustration, and many of the other fifty two O/B

\footnotetext{
${ }^{14}$ Rudyard Kipling, “Outward Bound Edition Preface,” Plain Tales From the Hills, The Writings in Prose and Verse of Rudyard Kipling, Volume I (New York: Scribners, 1897), XV, The description of Lockwood's illustrations appears on an unnumbered page, apparently meant to be XVII, of the same volume. John Lockwood Kipling Arts and Crafts in the Punjab and London, ed. Julius Bryant and Susan Weber (New Haven: Yale University Press, 2017), 97-99, 294 prints color photograph of four of the six bas-reliefs, which are described by the editors as "bas-reliefs," 97, made of "plaster," 97-99, 294 two of which are gray, and two of which are "bronzed," 99, or with "bronze patina," 294. The bas-reliefs described in the exhibit book should be in the exhibit itself at Bard College Graduate Center Gallery, New York City, Sept. 15, 2017 to January 7, 2018.

${ }^{15}$ Heinrich Wolfflin, Principles of Art History (New York: Dover, 1952). See Wilhelm Worringer, Abstraktion und Einfühlung, mit ein Vorwort zur Neue Ausgabe (Munich: Piper, 1959), 184.
} 
illustrations, are also expresssionist, or else what I will call romanntic-expressionist, a point that leads us directly to Worringer, Read, and expressionism as such, as well as its complex relationship to romanticism.

Wilhelm Worringer published Abstraction and Empathy in 1908 just as German and Central and Northern particularly Germanic European expresionism was itself developing. Worringer questioned and creatively incorporated into his aesthetics the results of two types of German aesthetics of his day. The first was the art history of Alois Riegl, who had explored nonrepresentational abstract art, of a geometrical nature, and largely left outside of the canon of the classics of Western painting and sculpture. Riegl, for example, had studied late Roman crafts. ${ }^{16}$ The second line of research came from Theodor Lipps, who had suggested that the emotion of empathy, Einfühlung, was particularly tied to the works of naturalism central to the classics of the Western canon of great painting and sculpture. ${ }^{17}$ Starting with these two lines of research Worringer asked what the emotional correlate of abstract, geometric art was. In asking this question he assumed that the answer was not empathy. Rather, the answer was essentially alienation and denial of the world. Thus, at this stage of his inquiry Worringer saw art as either naturalistic and empathic or abstract and life denying. ${ }^{18}$

However, Worringer developed an extended, tripartite as opposed to dualistic, version of his empathy theory: abstract art which was neither as geometrical as the art studied by Riegl, nor as naturalistic as the art studied by Lipps, but a distorted version of natural life. Such work aroused emotion between anxious denial and empathic affirmation.

Worringer concluded Abstraction and Empathy with a long discussion of Northern, particularly Germanic, art as the most representative example of the middle style between life and denial of life. ${ }^{19}$ Two years later Worringer published Form in Gothic, where the Northern Germanic Gothic style continued to be his prime example. Worringer's description of its style brings out fully the meaning of Northern Germanic Gothic art.

Gothic art being essentially abstract, and yet at the same time strongly vital, shows us that a differentiated intermediate state exists in which the dualism is no longer sufficiently strong to seek artistic freedom in the absolute negation of life, but is on the other hand not yet so weakened to derive the meaning of art from the organic orderliness of life itself. Therefore the Gothic will to form.... resolves itself into a confused mania of ecstasy, a convulsive yearning. ${ }^{20}$

Although the affinities between Northern Germanic art and the expressionism that was then developing in Germany and Central and Northern Europe are clear in Worringer, it was his English follower, Herbert Read, who most explicitly tied the jagged lines of Northern Germanic art to the new expressionist art. ${ }^{21}$

Expressionist artists were fond of depicting beings such as monsters or robots. These figures could be empathized with as having similarities to humanity, but they also conjured up terror and disassociation because of their distorted and nonhuman characteristics. It was a short path from this third type of emotion to classic German

\footnotetext{
${ }^{16}$ Wilhelm Worringer, Abstraktion und Einfühlung, 55-56. See Alois Riegl Spăatromische Kunstindustrie (Vienna: Vero, 1991).

${ }^{17}$ Worringer, Abstraktion und Einfühlung, 40, cites Theodor Lipps Aesthetik, but does not give a full reference to the book.

${ }^{18}$ Worringer, Abstraktion und Einfühlung, 55-60.

${ }^{19}$ Worringer, Abstraktion und Einfühlung, 148-164.

${ }^{20}$ Wilhelm Worringer, Form in Gothic, with an Introduction by Herbert Read (New York: Schocken, 1957), 68. See Wilhelm Worringer, Formproblem der Gothik (Munich: Piprt, 1910), 49-50.

${ }^{21}$ Herbert Read, Introduction, to Form in Gothic; Art and Alienation (New York: Viking, 1967), 66, 72, 74, 107, 127-128, 142, 157; The Philosophy of Modern Art (London: Faber and Faber, 1977), 100, 216, 217-218. For a full recent account of the relation between expressionism and Northern Germanic Gothic art, see Magdalene Bushart, "Chagging Times, Changing Styles: Wilhelm Worringer and the Art of his Epoch," in Neil Donahue, ed., Invisible Shadows The Expressionist Art History of Wilhelm Worringer (University Park, Pennsylvania, Pennsylvania State University Press, 1995), 70-85.
} 
expressionist films such as Murnau's Nosferatu. Such figures represent the border between that with which we can and cannot empathize.

Much expressionist art tilts very close to that part of the border where we cannot or almost cannot empathize. I call this expressionism horrific, or tilting toward the horrific. But when expressionist art remains clearly on the border between what we can and cannot empathize with, my name for it is alienation expressionism. This dichotomy between the two tendencies in expressionism, horrific and alienation, is further complicated by the fact that expressionism can be tied in various ways to romanticism, in which case I call it romantic expresionism. Although horrific expressionism can also be linked with romanticism, the more common link is between romanticism and alienation expressionism: romantic alienation expressionism.

What is needed, however, is a specific aesthetics which can account not only for empathy, but also for the depiction of empathy in the animal and animal-human world, particularly when that emotion is played ambiguously against other and even contradictory emotions. My basic idea in my earlier environmental aesthetics was that aesthetic appreciation of nature must be tied to the concept of self-realization, as, for example, in the environmental ethics of Naess, and in the aesthetics of Friedrich Schiller, Herbert Marcuse and Ansel Adams. ${ }^{22}$ This environmental aesthetics best fits Lippschen empathy with beings that are depicted naturalistically. For beings that are depicted in terms of Worringer's middle path between naturalism and abstraction, what is needed is an aesthetics of alienation expressionism. Alienation expressionism can depict empathy of the sort emphasized by Peter Reed, i.e., empathy for beings that are completely or partially different from us. Furthermore, alienation expressionism fits the empathy depicted in Rudyard's Jungle Books and Lockwood's and Watson's illustration for them better than any naturalistic art form.

The greatest stories in the Jungle Books bear out the truth of Bonamy Dobrée's claim that Rudyard's greatest works combine fantasy and realism. ${ }^{23}$ It was Lockwod's and Watson's genius to have transmitted this vision into visual art. Rudyard himself emphasized how in the Jungle Books he gave his daemon-a symbol of fantasy, myth and imagination—full reign. ${ }^{24}$ For Rudyard entrance into the animal world was often accompanied with entrance into a world of fantasy. Rudyard's fantasies set in India-including the Jungle Books - are sometimes merely eerie, and thus are best illustrated with horrific expresionism. At other times they utilize the ambiguity of the border between the naturalistic and fantastic, and are best illustrated with an alienation expressionism that points to the border between achieving empathy and not achieving it. At other times they point to a realm of expanded empathy beyond ordinary reality, and are best illustrated with romanticism, or romantic expressionism.

Yet what may appear to be merely horrific may add to the empathy. It would be hard to find an entrance into another world of empathy in the horrific story of a fall into an uncanny valley of living dead, "The Strange Ride of Mowbray Jukes.” This completely horrific fantasy appeared originally in the same fantasy collection, The Phantom Rickshaw and Other Eerie Tales, as "The Man who Would be King” which, along with its horrific elements, is a genuine story of entrance into a world of empathy outside ordinary reality. ${ }^{25}$

\footnotetext{
${ }^{22}$ Norman Fischer, “From Aesthetic Education to Environmental Aesthetics,” Clio 25.4 (1996), 365-391.

${ }^{23}$ Bonamy Dobrée, Rudyard Kipling Realist and Fantasist (Oxford: Oxford University Press, 1967).

${ }^{24}$ Rudyard Kipling, Something of Myself (London: Macmillan, 1937), 210.

${ }^{25}$ Rudyard Kipling, "The Strange Ride of Mowbay Jukes," "The Man Who Would be King," in The Phantom Rickshaw and Other Stories (New York: Scribnerss, 1897), originally published in The Phantom Rickshaw and Other Eerie Tales (London: A. H. Wheeler and Co., Indian Railway Library, 1888).
} 
Lockwood's illustrations for both of these stories in the O/B edition, bring out this duality. He appropriately follows horrific expresionism for "The Strange Ride of Mowbray Jukes.” (see Figure 1). His style is romanticism with a dash of romantic expressionism, for "The Man Who Would be King" (see Figure 2). Both must be contrasted with the alienation expresionism of Lockwood's O/B illustration of "The Incarnation of Krisnha Mulvaney"26 (see Figure 3).

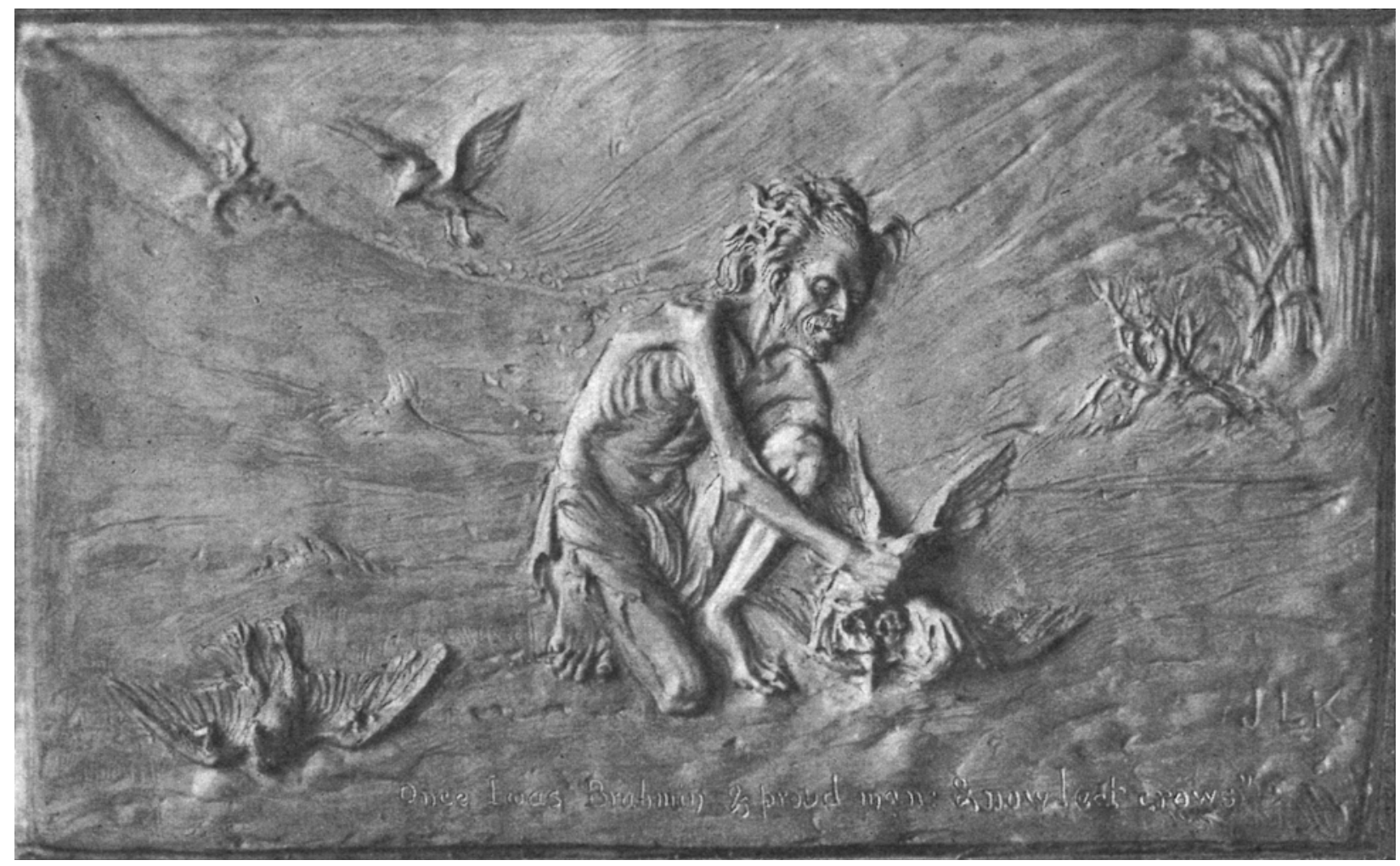

Figure 1. The Strange Ride of Mowbray Jukes, 226.

${ }^{26}$ Soldiers Three and Military Tales (New York: Scribners, 1897). 


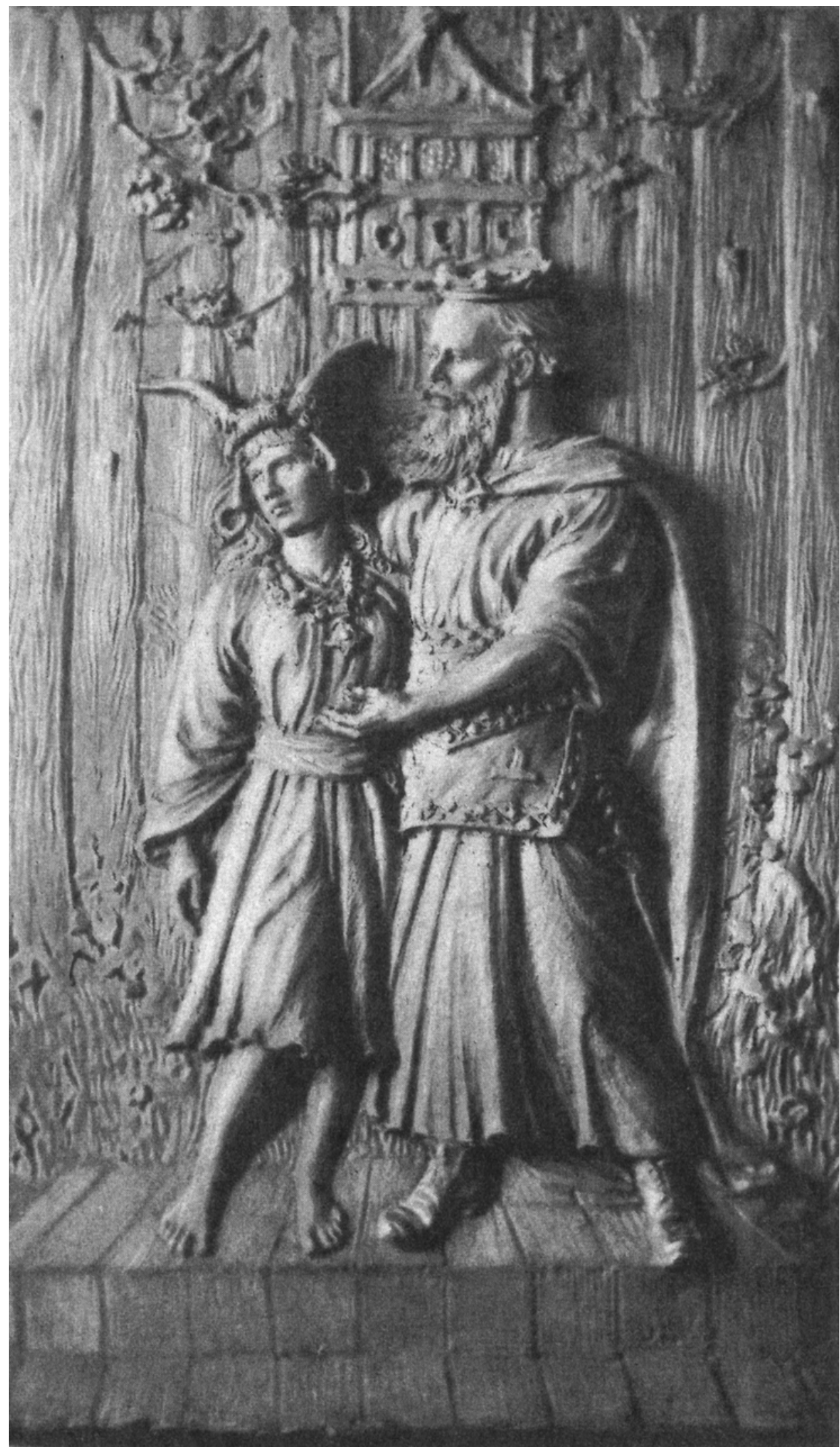

Figure 2. The Man who would be King, Frontpiece. 


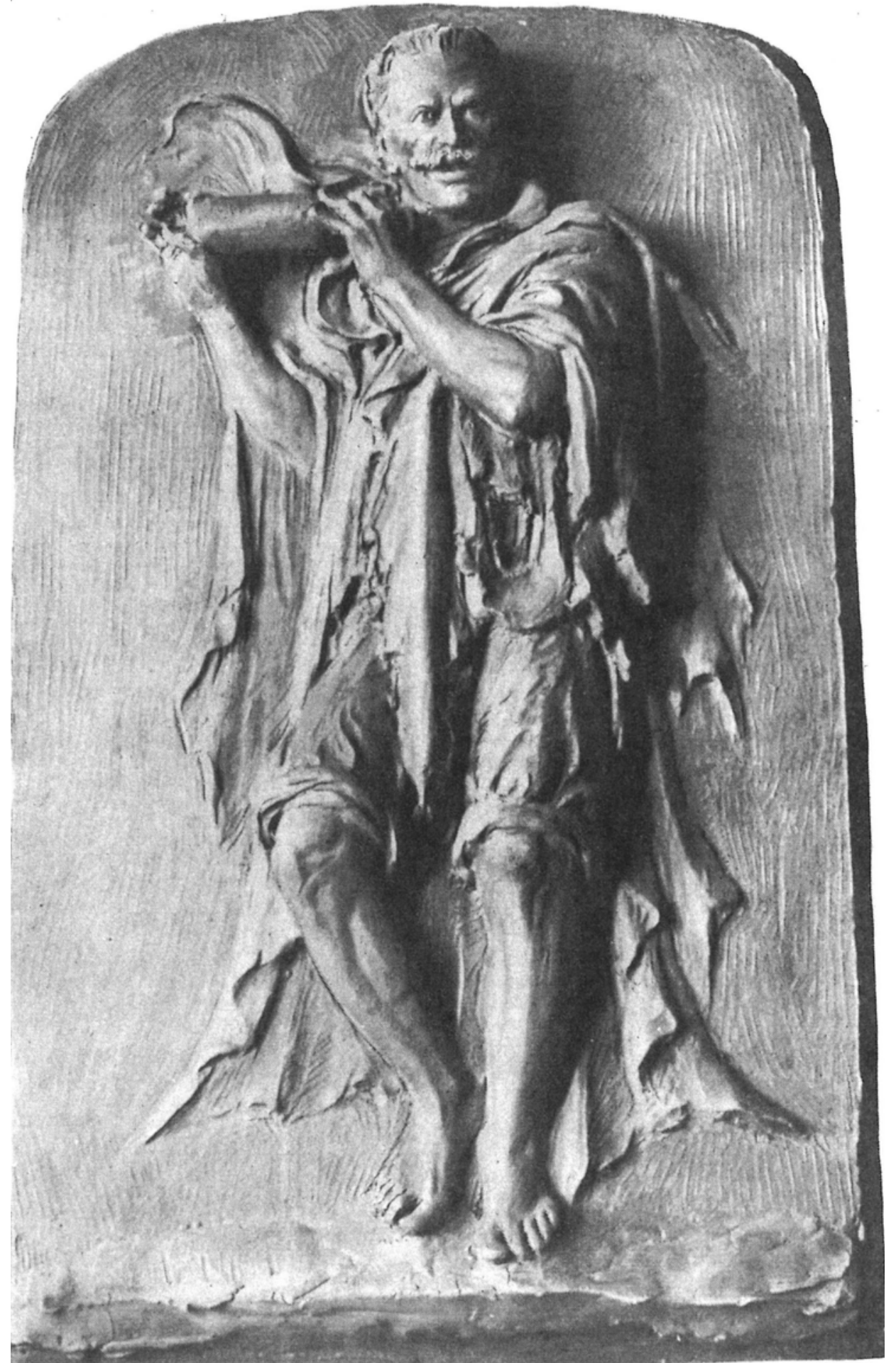

Figure 3. Mulvaney as Krishna, 86. 
Lockwood's O/B Jungle Books illustrations can be analyzed in terms of the dichotomy of alienation expresionism and romantic expressionism, but they resemble his illustration for "The Man Who Would be King” and "The Incarnation of Krisha Mulvaney" more than his illustration for "The Strange Ride of Mowbray Jukes." Mowbray Jukes' strange and "eerie” ride into a canyon of half dead people presents a horror fantasy that does not lift us into a new plane of reality where we can empathize with the other in new ways. It is a fantasy tied only to the most brutal of realms, and there are elements like this also in Rudyard's Jungle Books, but Lockwood avoided them in his $\mathrm{O} / \mathrm{B}$ Jungle Books illustrations. The incarnation as Krishna of empathic member of the famed soldiers three, Terence Mulvaney, as he rides on an unruly elephant, certainly represents alienation expressionism. But Rudyard's empathy expanding fantasy stories set in India often depict a journey into an unknown, mysterious and at least seemingly better world. Thus, in contrast to his use of alienation expresionism for "The Incarnation of Krishna Mulvaney,” and his use of horrific expresionism for “The Strange Ride of Mowbray Jukes,” Lockwood used a romantic and romantic expressionist form to illustrate Rudyard's famous story of British soldiers on heir way in Afghanistan, "The Man who would be King."

I am using these three O/B illustrations as entrance into Lockwood's and Watson's Jungle Books illustrations, because the $58 \mathrm{O} / \mathrm{B}$ illustrations present a unified form, and it is worth while seeing it both in its Jungle Books and wider application.

Worringer's aesthetics leads us away from any attempt to interpret romanticism and expresionism solely in terms of a primarily physical concept of visual form. Following the aesthtics of the great English aethetician, R. G. Collingwoood leads us, rather, to look for the lost emotion and imaginative expression behind the physical visual form. ${ }^{27}$ The master emotion that inspired Rudyard was that entrance into a fantasy or supernatural world and entrance into the animal world often went together. The three roles of animals-as symbols of the horrific, as symbols of alienated empathy, and as symbols of lifting us out of the ordinary world into a mysterious and romantic world of empathy_run through Rudyard's Jungle Books, and are echoed in the illustrations of Lockwood and Watson. They all use romanticism, and romantic, horrific, and alienation expressionism to unlock the secret of that emotion.

In the Jungle Books the two approaches to animals of Lockwood Kipling and Seton combine to develop a philosophically complex concept of empathy in the animal human relationship, with Lockwood's influence putting animals more in the context of society and civilization, and Seton's influence taking them out of that social context into the pure wild, but with both influences inculcating greater empathy for animals. Some Jungle Books stories do not achieve this complexity, but rather set the stage for it. All the Jungle Books stories are truly stories of empathy in the animal and animal-human world that express Rudyard's emotions, but sometimes the world they depict is a world of human concerns, domination of animals by humans, and militarism. As a result sometimes the stories expand empathy for animal life, and sometimes they do not, a creative tension which actually makes Rudyard's achievement richer aesthetically, because his conflicting emotions are expressed. This complexity is captured in Lockwood's and Watson's illustrations.

Looking at empathy in the animal human relation in the Jungle Books in the light of the direct influences of Lockwood's and Seton's depiction of empathy for animals, allows us to comprehend the stories according to (1)

${ }^{27}$ R. G. Collingwood, The Principles of Art, Chapter VI, “Art Proper (1): as Expression;” Chapter VII, “Art Proper (2): as Imagination.” 
how much empathy they depict in the relations between animals and humans and animals; and (2) how much they depict an alienation effect, a shaking up of the deepest parts of the human personality, and also a shaking up that is cured by empathy with the other: animal with animal, animal with human, human with animal. The two concepts are linked, because the shaking up process creates a kind of stripping down of the human being to the most basic fears and hopes, what the great existentialist Kierkegaard called "fear and trembling," a state of mind which makes possible an empathic entrance into another world, namely the animal world. ${ }^{28}$ The combining of these two themes can be illustrated visually with romanticism, alienation expressionism, romantic expressionism, romantic alienation expresionism, and even horrific expresionism. Lockwood's and Watson's romantic, romantic expresssionist, alienation expressionist, and romantic alienation expressionist illustrations bring out these themes particularly well, by depicting an existentialist tension and also a romantic aspiration in the heart of the jungle. Expressionist art, particularly in its alienation form, is well suited for expressing existential fear and trembling, because of its emphasis on tension inducing angles and distortions, whether done through line or color. When expressionism turns toward alienation these existential tensions are exacerbated. But when expressionism is romantic it depicts a Platonic upward quest out of these tensions. The Jungle Books depict: (1) an empathy with the other that cures; (2) a fear and trembling that causes the empathy that doubles back and cures the fear and trembling.

\section{Part Four: Selected Jungle Books Stories Seen in the Light of One, the Intellectual History Behind Kiplingesque Empathy in the Jungle Books; Two, Key Philosophies of Animal and Animal-Hman Empathy; and Three, A Philosophy of Art Aistory Ahat Explains the Empathy Depicting Power of Lockwood's and Watson's Illustrations}

Part Four concentrates on stories and illustrations that emphasize the empathy theme. As in a number of the seventeen O/B volumes with Lockwood's illustrations, in the O/B Jungle Book and Second Jungle Book, the stories are rearranged from the first editions. Mowgli and nonMowgli stories were interspersed in the 1894 Jungle Book and 1895 Second Jungle Book. In the O/B editions all the Mowgli stories are in The Jungle Book, and all the nonMowgli stories in The Second Jungle Book. For the most part the 1948 Doubleday edition follows this new arrangement. All references are to the O/B editions.

\section{The Mowgli Stories}

I am following the Doubleday order: (1) "Mowgli’s Brothers; (2) "Kaa’s Haunting”; (3) "How Fear Came”; (4) “Tiger! Tiger!”; (5) “The King’s Ankus”; (6) "Letting in the Jungle”; (7) "Red Dog”; (8) "The Spring Running". The only differences between this order of the eight stories and the O/B order is that the latter places "Letting in the Jungle" before "The King's Ankus."

Lockwood's illustration for (1) "Mowgli's Brothers" reshapes it into a story of animal and human solidarity. The story begins with the kind of wild cry, typical of expressionist literature: "This is the hour of pride and power, talon and tooth and claw. ${ }^{29}$ Mowgli is depicted as safe with his adopted wild wolf parents, but dangerous

\footnotetext{
${ }^{28}$ Soren Kierkegaard, Fear and Trembling and the Sickness Unto Death (New York: Doubleday/Anchor, 1954), for Kipling’s affinities with existentialist writers in his purely human stores See my "Rudyard Kipling's Stories of Overcoming Existential Angst Through Empathy,” Janus Head, Volume 12, No. 2, 2011, 259-268; “Empathy in Kipling's Stories of Humans and Dogs.” The Kipling Journal. Volume 87, No. 4 December, 2013, 32-42.

${ }^{29}$ Rudyard Kipling, “Mowgli’s Brothers,” Unnumbered page at beginning.
} 
wildness first comes with the madness of Tabaqui, the jackal, who warns them that Shere khan, the tiger, is close by. ${ }^{30}$ For the wolves, the tiger has no right to change quarters without warning, especially when he is hunting bullock, buck and man. Indeed, hunting man is regarded by the wolves as unsportsmanlike. ${ }^{31}$ In contrast to the unlawful Shere khan, the wolves as "free people" are taking orders from the head of the pack. ${ }^{32}$ Yet, Shere Khan has a claim on Mowgli, and he wants his fair due. ${ }^{33}$ This debate is not understandable completely in terms of ethical rules internal to jungle animals. Rather, it is soon revealed that the Jungle Books possess, right from the start, a Lockwood Kipling like cry for empathy with animals. For Akela, the leader of the wolf pack, had once fallen in a trap and been beaten and left for dead, so he knows what men can do. ${ }^{34}$

Throughout "Mowgli's Brothers," the rules and taboos that emerge bear witness to the interlinked fates of what Lockwood called "Beast and Man in India." Bagheera, the black panther, for example, trades a bull that he has killed for Shere khan's claim on Mowgli's life, so as a result Mowgli must never touch cattle. ${ }^{35}$ But often also the theme is of the sharp separation between "Beast and Man." Bagheera wears a mark from a chain around his neck, testifying to the cruelty of man, one of Seton's chief themes. ${ }^{36}$ Yet, the wolves are also cruel in their willingness to kill the old leader, Akela. When Mowgli intervenes in this struggle, it is said that he will go back to man or be killed in the wolf council. ${ }^{37}$ Mowgli does not as such go back to man at this stage, but he takes fire from the village, noting that before he was a wolf he lay before the "red flower." ${ }^{38}$ But still, the pack wants to kill him, and Akela promises that for the honor of the pack, he will not fight at the end, if the pack lets Mowgli go. At the end Mowgli is not killed and Akela does not die. ${ }^{39}$ Mowgli, Bagheera and Akela fight successfully against the pack, but the story ends not in triumph, but in Mowgli's tears. ${ }^{40}$ These tears symbolize the shifting boundaries between Mowgli's human and animal worlds.

Lockwood in his O/B illustation of the story chose romantic expressionism to refect the solidarity between human and animal of Mowgli's life witt the wolves—over horrific expressionism and/or alienation expressionist existetnialist fear and trembling.

Lockwood: The jungle is a place of solidarity between humans and animals.

\footnotetext{
${ }^{30}$ Ibid., $1-2$.

${ }^{31}$ Ibid., 3-4.

${ }^{32}$ Ibid., 7.

${ }^{33}$ Ibid., 5.

${ }^{34}$ Ibid., 10.

${ }^{35}$ Rudyard Kipling, "Mowgli’s Brothers,” 10.

${ }^{36}$ Ibid., 19.

${ }^{37}$ Ibid., 13.

${ }^{38}$ Ibid., 24.

${ }^{39}$ Ibid., 27.

${ }^{40}$ Ibid., 30.
} 


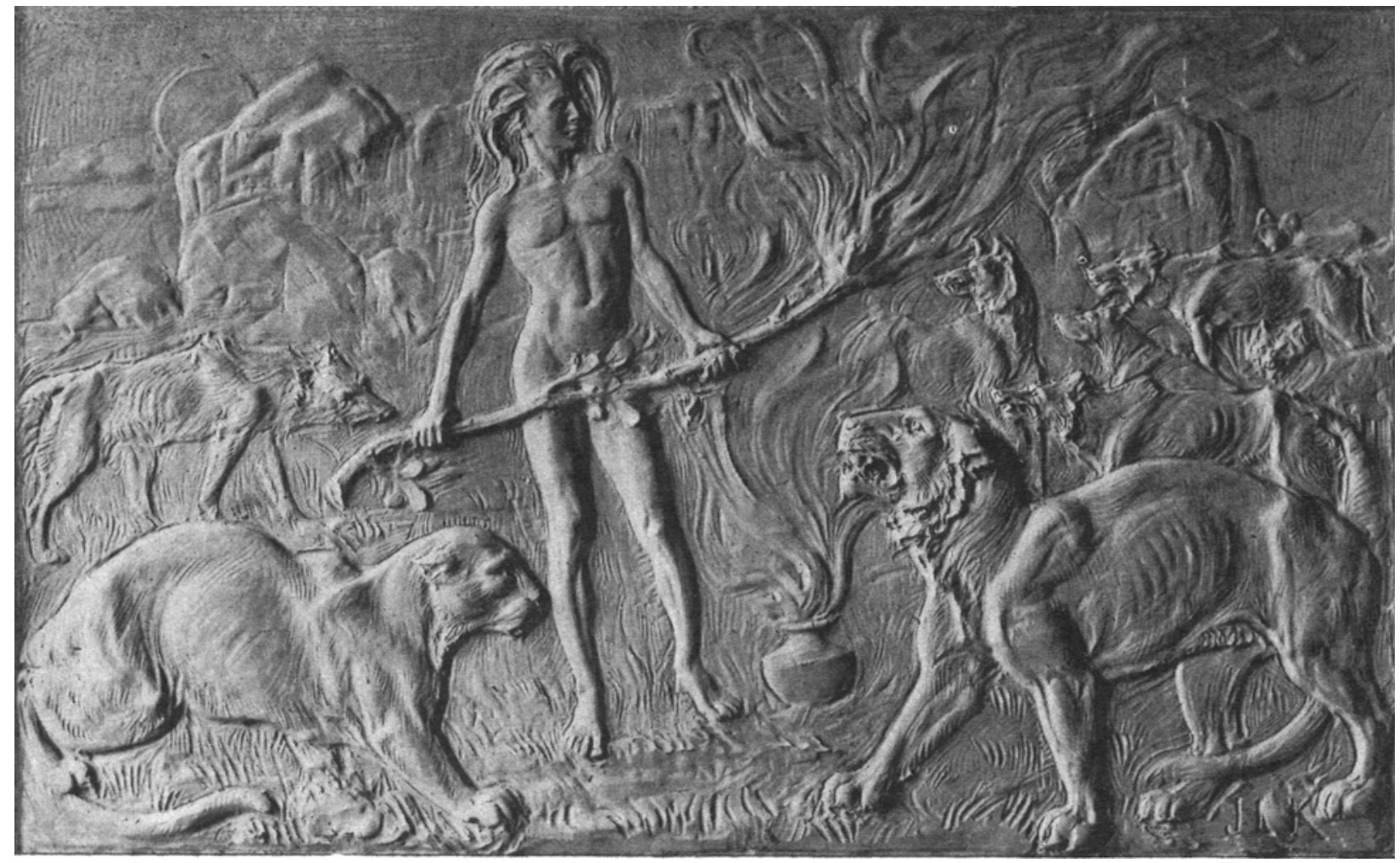

Figure 4. Mowgi’s’ Brothers, 28.

In (2) "Kaa’s Hunting," when Mowgli is kidnaped by the monkeys he enjoys the idea that he will lead his tribe of "Bander log" through the branches. ${ }^{41}$ Mowgli is finally rescued from the monkeys by Bagheera and Kaa, with Kaa's off stage killing and eating of the monkeys one of the most brutal scenes in the Jungle Books. ${ }^{42}$

It is not logical to go from these two stories directly to "Tiger! Tiger!," where Mowgli returns to his Indian village home, ultimately to use his residency there to launch his final hunting down and killing of Shere Khan, and then to assert his dominance over the wolves by showing them that he has killed the tiger.

In the rearranged $\mathrm{O} / \mathrm{B}$ and Doubleday editions the systole and diastole of empathy with and hatred for both humans and animals that begins with "Mowgli's Brothers" and "Kaa's hunting," becomes so powerful that it breaks the simple tripartite schema of the 1894 Jungle Book Mowgli story, not only chronologically, but also thematically. In the 1894 Jungle Book Mowgli is simply the boy who: (a) is raised by wolves and fights with a tiger; (b) fights alongside a bear, panther and python against monkeys; and (c) leaves the wolf pack and returns to the village, only to come back and assert not only his dominance over, but also his separateness from, the wolves. The O/B and Doubleday editions destroy this human triumphalist theme and human triumphalism of the ending Mowgli story of the 1894 Jungle Book, "Tiger! Tiger!” is now put after "How Fear Came,” an existentialist hymn to solidarity and empathy with and between animals. In addition, in the Doubleday edition alone (3) "How Fear Came” (4) "Tiger! Tiger!,” and (5) "The King’s Ankus” are put in front of (6) "Letting in the Jungle,” so that great anthem against human domination can be put directly in front of stories that conclude the Mowgli epic in

\footnotetext{
${ }^{41}$ Rudyard Kipling, “Kaa’s Hunting,”, 39-40.

${ }^{42}$ Ibid., 55-57.
} 
the Doubleday edition, (7) "Red Dog," and (8) "The Spring Running.” Thus, the Kiplings and the Doubleday editors ensured that the killing of the tiger no longer gives a tirumphalist message of human domination at all. Of course, Mowgli eventually does go back to Indian life, in (8) “The Spring Running.” But in the Doubleday edition he goes back to man only after the themes of (one) human and animal empathy and (two) existential fear and trembling are revealed in (3) "How Fear Came,” (5) “The King’s Ankus,” only after he speaks his anthem against human domination in (6) "Letting in the Jungle," only after he joins with the other animals in the fight to the death against (7) "Red Dog;” only then can a non triumphalist Mowgli return to the village in (8) "The Spring running." The human triumphalism envisaged in (4) "Tiger! Tiger!," is modified by the unfolding crises of fear and trembling in the middle of the jungle, and the empathy that cures it into the muted reinsertion into Indian society of (8) "The Spring Running."

(3) "How Fear Came," tells a dramatic story of how all animals in the jungle, and Mowgli as well, suffer through a drought, and how they gather at a special watering place, where they are told to drink the water, not defile it, because they are suffering together. ${ }^{43}$ The animal who wants to defile the water, with blood, is Shere khan, because it is the one night that he is allowed to kill man. The suffering of the animals and Mowgli, along with the mystery of Shere Khan's right to kill man, leads to the telling of the story of how death, shame and fear came to the jungle. ${ }^{44}$ Out of this suffering there developed not only the split between "Beast and Man," but also the split between carnivores and noncarnivores. ${ }^{45}$ Watson used his alienation expressionist art to bring out the intensity of the suffering, and existentialaist fear and trembling, by putting the green forest in the background, and in the center a distorted mass of red and pale yellow, symbolizing the heat brought on by the drought; and in a black and white illustration, a lone leopard leaping across an empty water bed.

Watson used alienation expressionism to depict the jungle as a place of physical suffering and fear and trembling.

\footnotetext{
${ }^{43}$ Rudyard Kipling, “How Fear Came,” 89

${ }^{44}$ Ibid., 94.

${ }^{45}$ Ibid., 102-103.
} 


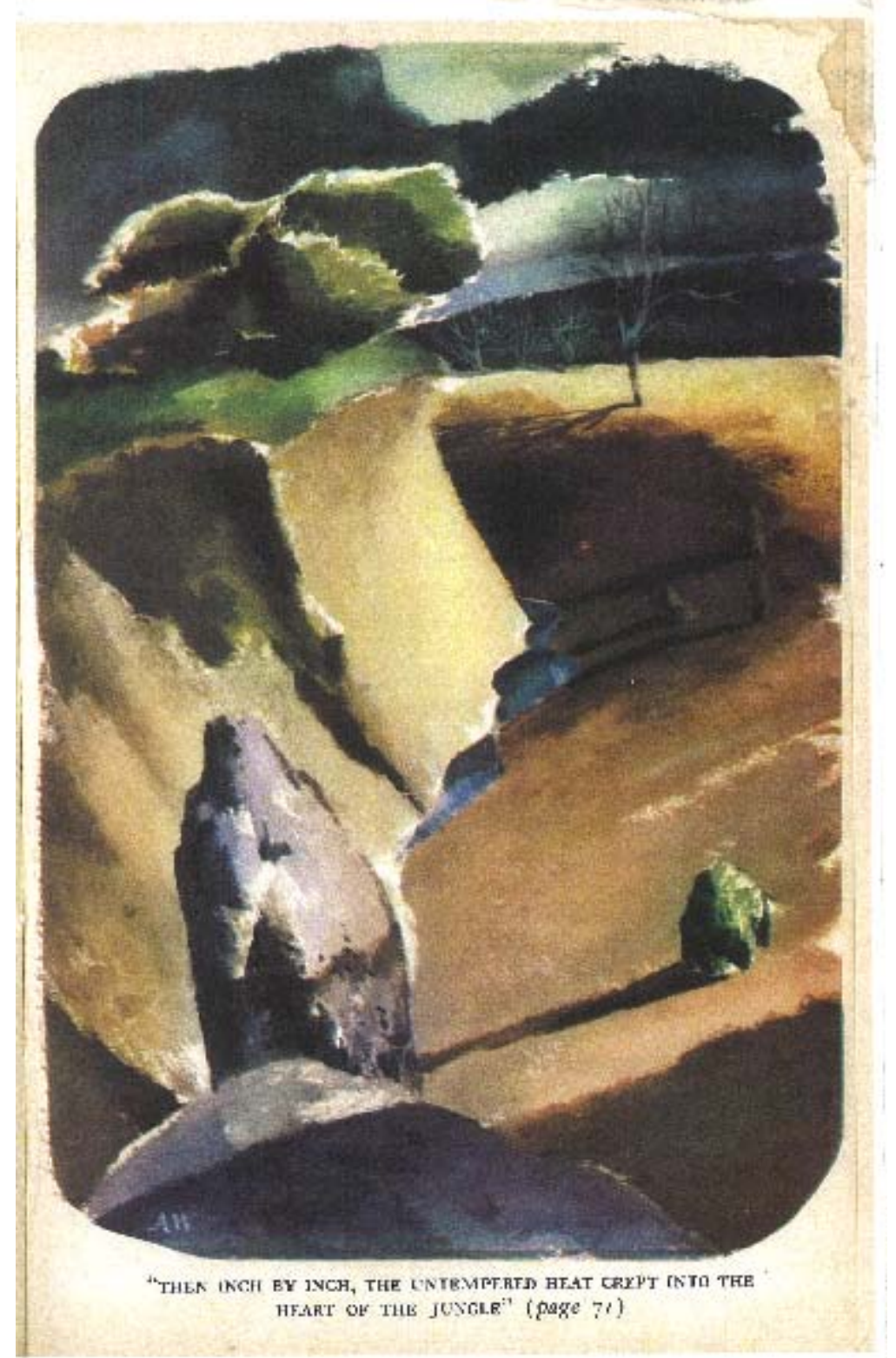

Figure 5. Then Inch by Inch, the Untempered Heat Crept into the Heart of the Jungle, 86.

Because in the Doubleday edition alone (4) "Tiger! Tiger!" is placed immediately after (3) "How Fear Came,” and just before (5) "The King's Ankus,” the result is that Mowgli's killing of Shere Khan in "Tiger! Tiger!,” and his struggle in that story with those in the wolf pack who follow Shere khan, coupled with his refusal to actually go back in a full sense into the village, is given deeper meaning. He must kill Shere Khan in "Tiger! Tiger!," because — as revealed in "How Fear Came” — the tiger is a defiler of the empathy between the animals in the jungle when they come together through suffering. He must not return to man ("Man goes to man in the end"), at least not yet, because man—as revealed progressively in “The king’s Ankus” and "Letting in the jungle” —is as much a defiler as Shere Khan. ${ }^{46}$

\footnotetext{
${ }^{46}$ Rudyard Kipling, “Tiger! Tiger!,” 134-135).
} 
(5) “The King's Ankus” returns to the scene of "Tiger! Tiger!,” with Mowgli bragging about killing Shere khan. ${ }^{47}$ As the story unfolds, a man appears on the jungle scene, and Mowgli asks, who is he with the knife? ${ }^{48}$ Thus starts the tale of human greed for treasure, played off against Kipling's description of the ecology of the place where the treasure is hid, in the wild lairs, within the ruins of a destroyed civilization, and now guarded by an ancient white cobra. ${ }^{49}$ At the heart of the treasure is the jeweled king's ankus. Men have been willing to die for this weapon for cruelly controlling an elephant, the death dealing aspects of which lead Mowgli to proclaim his sympathy for life when he promises that he will never kill again except for food. ${ }^{50}$ But the empathy for life goes beyond even this principle. The blood thirst brought on by the ankus leads Bagheera to pinpoint the link between the ankus and human blood thirst against animals, as well as against their own kind, and to testify to his knowledge of how in the end men follow the money. ${ }^{51}$

In the Doubleday edition alone, it is only now that we can turn to the Mowgli story that most illustrates a dramatically expanded empathy for animals perspective, coupled with anger at human exploitation of animals, which Mowgli and the animals respond to by "Letting in the jungle" on a village. The story best gives up its secret when placed in its Doubleday order, as the gateway out of the opening Mowgli stories (1) with the pack in "Mowgli's Brothers;” (2) with Bagheera, Baloo and Kaa in "Kaa’s Hunting;" with all suffering animals and against both Shere Khan and humans in (3) "How Fear Came," into the scene where Mowgli becomes the lord of the Jungle at the end of (4) "Tiger! Tiger!;” and against human blood thirst against man and animals in (5) "The King’s Ankus.” For with (6) "Letting in the Jungle,” Mowgli emerges as a very different Lord of the Jungle, a lord of the Jungle against human domination. With "Tiger! Tiger!” put in its proper order there is not such a break between its human triumphalism and the critique of human domination in (6) "Letting in the Jungle." After the existential fear and trembling of "How Fear Came," the herding life that Mowgli takes up in the village scenes at the opening of "Tiger! tiger!," seems a bucolic relief. ${ }^{52}$ Mowgli is simply back with another pack, as Akela acknowledges. Man is split, animals are split, and Mowgli proclaims that he is two Mowglis. ${ }^{53}$ But in the Doubleday edition alone, this split Mowgli emerges as scourge of human domination, slowly in "The King's Ankus," and then swiftly and dramatically in "Letting in the Jungle."

(6) "Letting in the Jungle" reveals Seton, more clearly than any other Mowgli story, as the second great influence on the Jungle Books. With Seton's ethics of animal rights and animal-human empathy driving it, "Letting in the Jungle" reverses in detail after detail a certain telos in the Jungle Books heading toward Mowgli's reinsertion into the human world of India, after his jungle life.

In "Letting in the Jungle” both Hathi, the elephant, and Bagheera, join in on destroying an Indian village and letting the jungle back in on it, partly out of reverence for Mowgli's grievances against humans, partly because of their own grievances against human exploitation of them. Hathi remembers the "Scar of the stake" that had caused him to suffer; Bagheera recalls the broken lock that allowed him to free himself from human captivity. ${ }^{54}$

\footnotetext{
${ }^{47}$ Rudyard Kipling, “The King’s Ankus,” 191).

${ }^{48}$ Ibid., 195.

${ }^{49}$ Ibid., 199.

${ }^{50}$ Ibid., 203.

${ }^{51}$ Ibid., 205-206, 212.

${ }^{52}$ Rudyard Kipling, “Tiger! Tiger!,” 119.

${ }^{53}$ Ibid., 131.

${ }^{54}$ Rudyard Kipling, “Letting in the Jungle,” 175.
} 
Mowgli himself described letting in the jungle in his "Song against People," as an act of empathy and mercy not only for the suffering of Hathi and Bagheera, but also for that of his adoptive human parents, whom he rescues from the villagers' wrath, a wrath that awoke because his adoptive parents had shown empathy and mercy for his suffering. ${ }^{55}$ The effect of the themes of violence, mercy, empathy and suffering in this story are enhanced by expressionist language and imagery, an imagery that is further enhanced in Watson’s existentialist and alienation expressionist illustration, which depicts the jungle overpowering the village as dominated by a single twisted and distorted green and menacing tree, at the center of a pale reddish and yellow landscape. Mowgli himself is described as a supernatural figure, "man, ghost or wolf of the jungle." 56 Bagheera and Hathi join in with Mowgli's war, when Hathi trumpets "Thy war shall be our war," and Bagheera snarls "What is Man... eater of earth? I have followed him., 57

The idea of letting in the Jungle may have come from Seton's "Raggylug." At a superficial level Molly Cottontail in that story dies because she is forced to swim an icy pond when chased by a fox. But the larger context is that Molly and her son Raggylug have been stripped of much of their ecological protection as the farmers whose land they live on pillage the natural places they called their home. Seton ended the story in hope by describing the relapse of the farm that served as their home into relative wildness, a kind of letting in of the jungle. $^{58}$

In Watson's alienated expressionist illustration, the jungle is a place of animal vengeance against human destructiveness toward animals.

\footnotetext{
${ }^{55}$ Ibid., 163-164.

${ }^{56}$ Ibid., 162

${ }^{57}$ Ibid., 175, 164.

${ }^{58}$ Ernest Seton Thompson, “Ragagylug,” 142-143.
} 


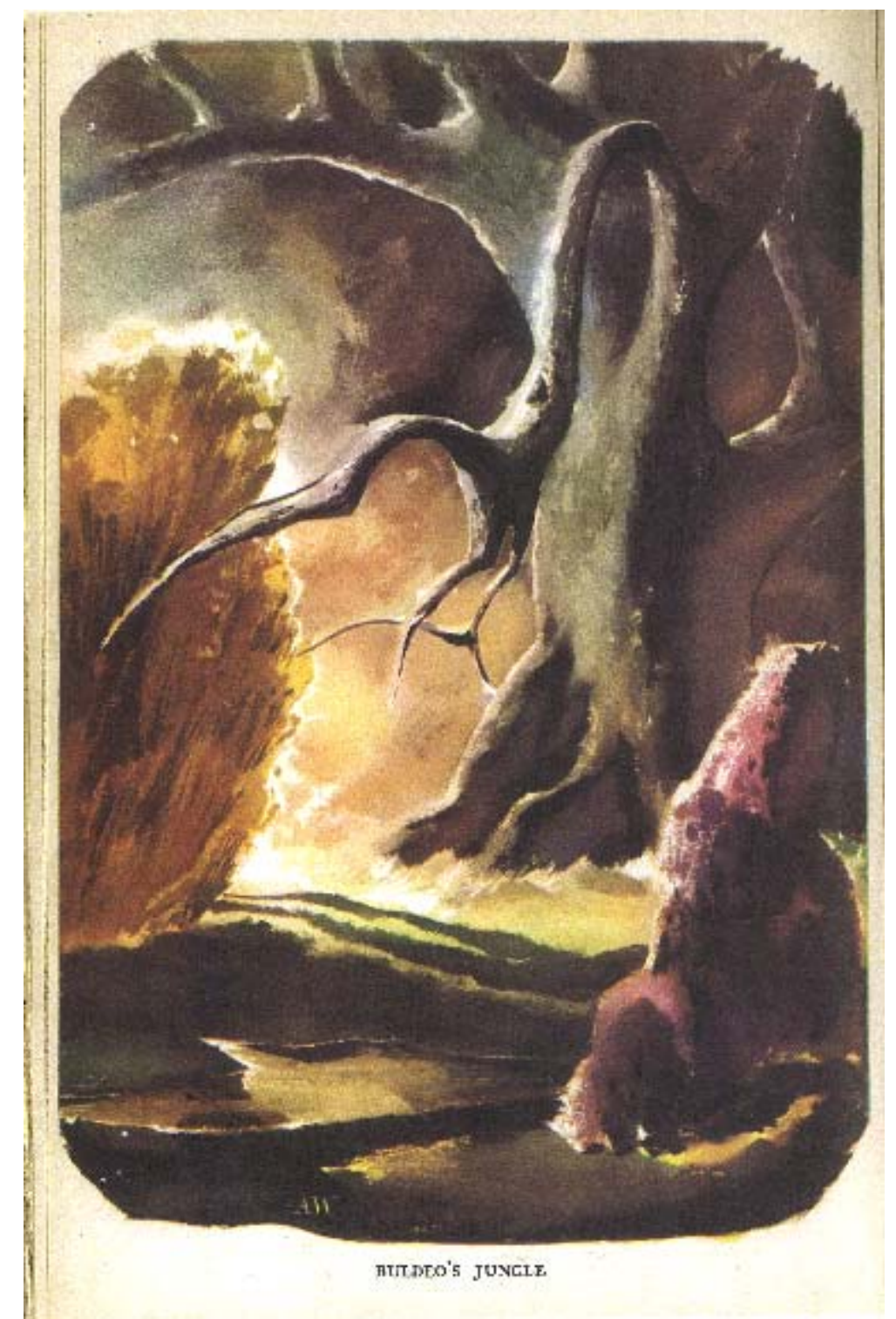

Figure 6. Buldeo’s Jungle, 190.

With "Letting in the Jungle" placed properly, this anthem against human domination of animals operates as the gateway to the final episodes of the Mowgli story: "Red Dog” and "The Spring Running”. In (7) "Red Dog” Mowgli emerges above all as heroic general of the tribe of wolves, saving them and the jungle from the invading army of red dogs; Mowgli is even criticized for his loyalty to the wolf pack by Kaa. ${ }^{59}$ Mowgli's physical struggle against the red dog is also existential, as Lockwood's alienation expressionist illustration shows. In it Mowgli dives, in a rigid pose, into the water in a trick to get the red dogs to do the same. The rigid body in Lockwood's illustration only appears to possess classical calm, and the tense lines in his expressionist depiction break any sense of calmness, and really depict Mowgli's inner struggle and tensions, as leader of the pack, to defend the pack. ${ }^{60}$

\footnotetext{
${ }^{59}$ Rudyard Kipling, “Red Dog,” 229-230.

${ }^{60}$ Rudyard Kipling, "Red Dog,” 248.
} 
Lockweed: The jungle is a place of existentialist tension.

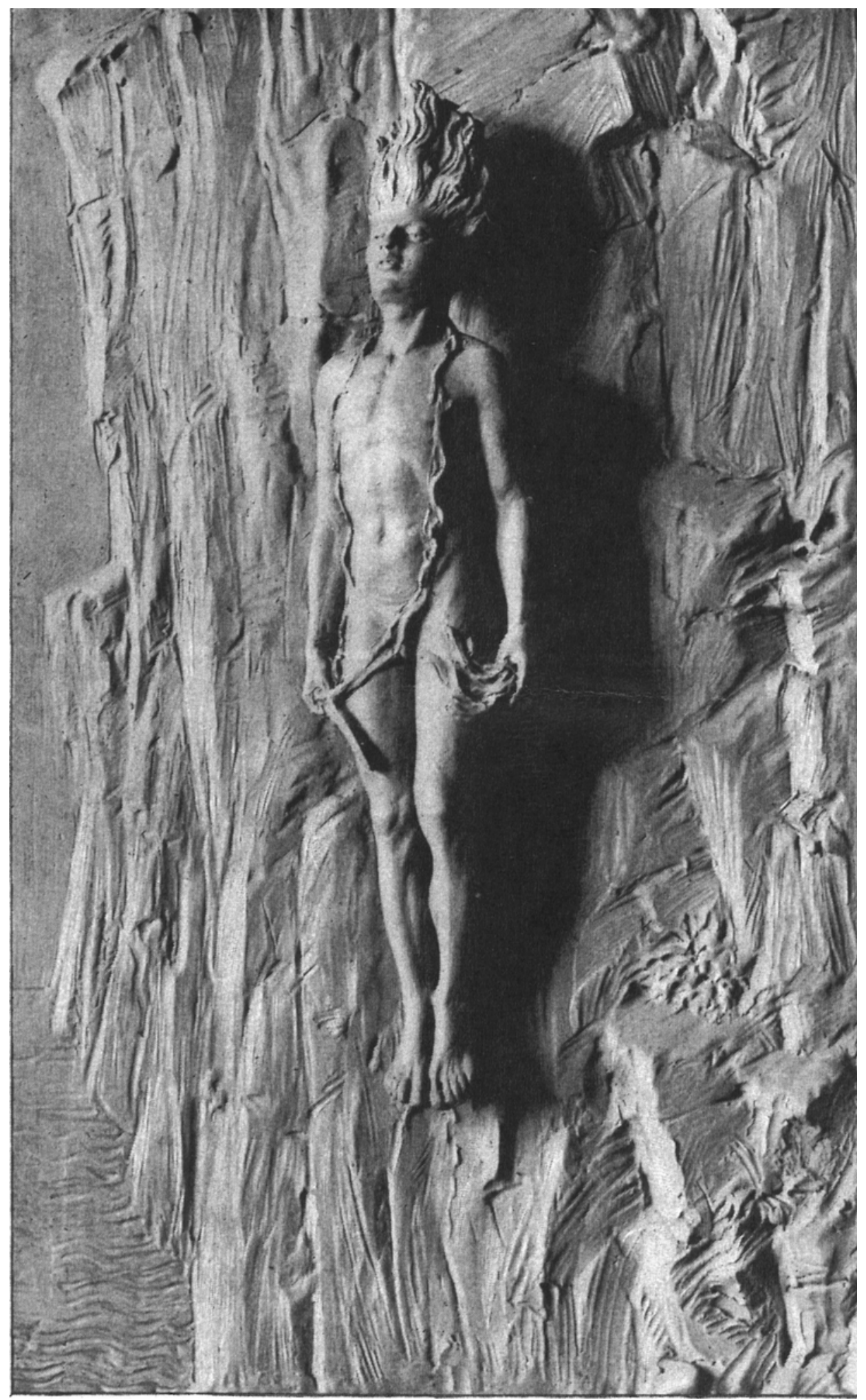

Figure 7. Red dog, 246. 
But the Mowgli story must end, and it cannot end on this note. (8) "The Spring Running” gives us at least one logical conclusion to the Mowgle epic. Mowgli returns, but the jungle is still with him, as shown by the "song of the animals,” displaying Kaa's adherence to strength within bounds, and Bagheera's contempt for jackal men. ${ }^{61}$ Thus, at the end, Mowgli is out of the Jungle, but the virtues, using virtue in the sense of classical political theory as involving moral strengths as well as moral values, remain with him, as long as he remains true not just to his animal friends, but also to what they represent. After his expressionist "Red Dog" illustration, Lockwood used reomantic expresiopnism in his illustration for “The Spring Running,” in which Mowgli’s animal friends and animal virtues lead him to be integrated into village life.

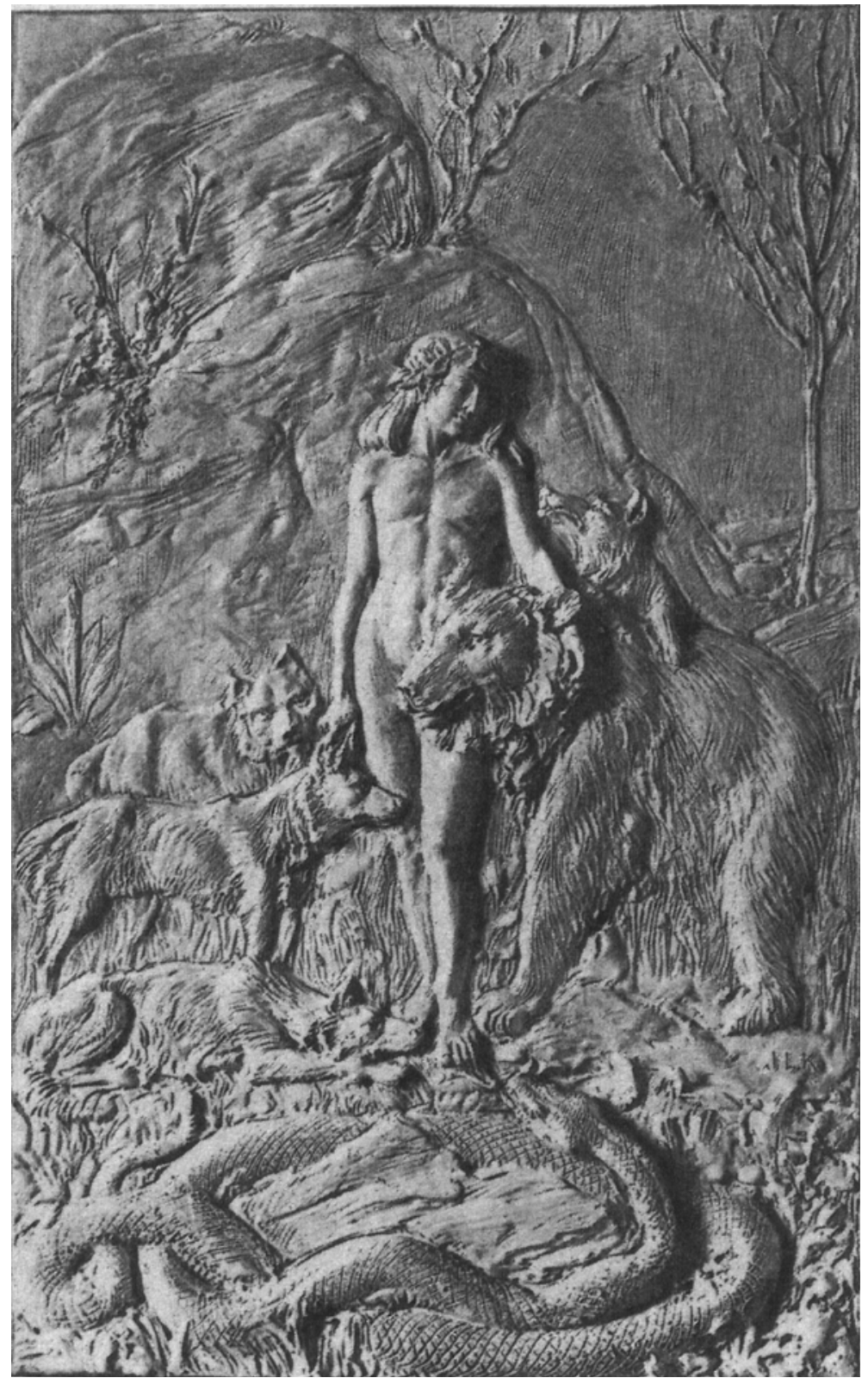

Figure 8. The Spring Running, Frontpiece.

${ }^{61}$ Rudyard Kipling, “The Spring Running”, 293-295. 
In Watson's romantic expression color illustration, the jungle is a place of light and homecoming.

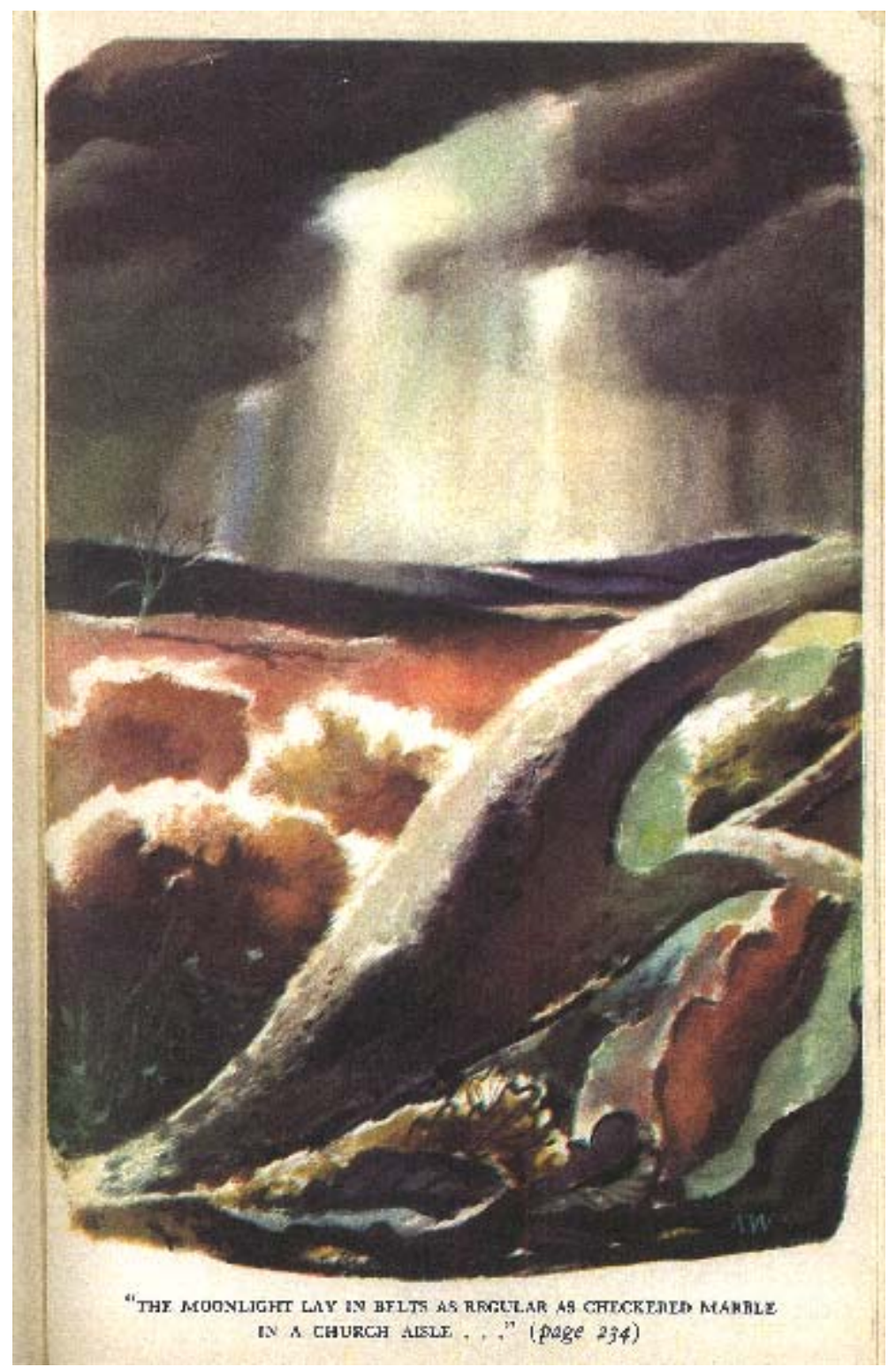

Figure 9. The Moonlight Lay in Belts as Regular as Checkered Marble in a Church Aisle... (page 234).

In Lockwood's romantic expressionist illustration, the jungle is a place of human and animal solidarity.

\section{Animal Stories Without Mowgli}

We can now continue to use the link between Lockwood, Seton, and Rudyard's vision of (one) empathy and (two) fear and trembling in the midst of the jungle, to interpret the non-Mowgli stories. I will thus follow the Kiplings' fundamental decision to treat the non-Mowgli stories as one complete whole which in 1897 they called The Second Jungle Book, and the Doubleday editors called Jungle Books, Volume Two. The order of the animals without Mowgli stories differs in each of these editions. I will follow the O/B order, but leave out the stories that are less important for the empathy theme. 
Seton had taught Rudyard, by the time he wrote (1) "The White Seal” that animals must have rights. ${ }^{62}$ Of course Seton did not state this explicitly until 1898, but the view that animals have rights is implicit in the story of the sufferings of Molly Cottontail and Silverspot, which we know Rudyard told Seton had influenced the Jungle Books, and in the story of Lobo, which Kipling probably had read before he wrote "The White Seal." Aside from the question of direct influence, "The White Seal”- along with "Letting in the Jungle” — represents one of the most complete critiques of human triumphalism against animals in the Jungle Books. In addition, it has special claim to be an animal rights story in Seton's sense, because like Molly Cottontail and her son, Raggylug, and like Lobo, the White Seal's suffering is directly caused by human exploitation. The rights thesis applies with particular strength to the white Seal, Molly Cottontail and Raggylug, because they all suffer at human hands. “The White Seal” also powerfully represents Lockwood's animal-human empathy influences.

"The White Seal" is not set in India, but rather on the Island of St. Paul in the Bering Sea. Perhaps Rudyard set "The White Seal” away from India so that he could describe interactions between humans and animals that he could completely despise. He places one of the most direct expressions of the Seton like attack on human domination of animals in the mouth of a sea lion, who tells a realistic tale of the ecology of seals and men, with the men absolutely winning, and the seals absolutely losing. ${ }^{63}$

There is something of Mowgli, the herder Kotick, the white seal, as he learns about this ecology by following the herding and killing of the seals by human trappers. ${ }^{64}$ Kotick's perception that the seals must completely end their subjugation to humans isolates him among the seals. ${ }^{65}$ Realizing his isolation, Kotick sets off to the "world's end."66

It is to the world's end that Kotick leads his pack of seals to safety from human exploitation and specifically to safety from being hunted down. ${ }^{67}$ Silverspot was not hunted by humans, and human hunting of Raggylug was not the main cause of his problems, while Molly Cottontail was not a victim of human hunting at all. But the ongoing Santa Fe Seton exhibit has brought out the importance of the theme of obsessional hunting of animals in Seton's New Mexico stories “Lobo" and "The Pacing Mustang," and the theme also dominates "Redruff," the ending story in Wild Animals I Have Known. ${ }^{68}$

It was Watson's perceptiveness to have seen that the "world's end” must dominate his illustration of this story, at the center of which is his metamorphosis of Kipling's description of the end of the world that Kotick finds- - "a stretch of deep water that ran out into the perpendicular cliffs,"- "into an expressionist vision of massive green water, small earth, and massive blue sky."69 Lockwood's "White Seal" illustration may seem understated next to Watson's romantic expressionist depiction of the "world's end," but Lockwood's "White Seal" and family seems to pour all his Hinduism and humane society empathy into an illustration that uses alienation expressionist distortion to depict not only tension and suffering, but also hope.

\footnotetext{
${ }^{62}$ Ernest Seton Theompson, “Note to the Reader," in Wild Animals I Have Known, 12-13.

${ }^{63}$ Rudyard Kipling, "The White Seal,” 43.

${ }^{64}$ Ibid., 40.

${ }^{65}$ Ibid., 45.

${ }^{66}$ Ibid., 41.

${ }^{67}$ Ibid., 56-59.

${ }^{68}$ David L. Witt, Ernest Thompson Seton: The Life and Legacy of an Artist and Conservationist, 34-38.

${ }^{69}$ Rudyard Kipling, "The White Seal,” 53.
} 
Watson: At the world's end seals can find peace.

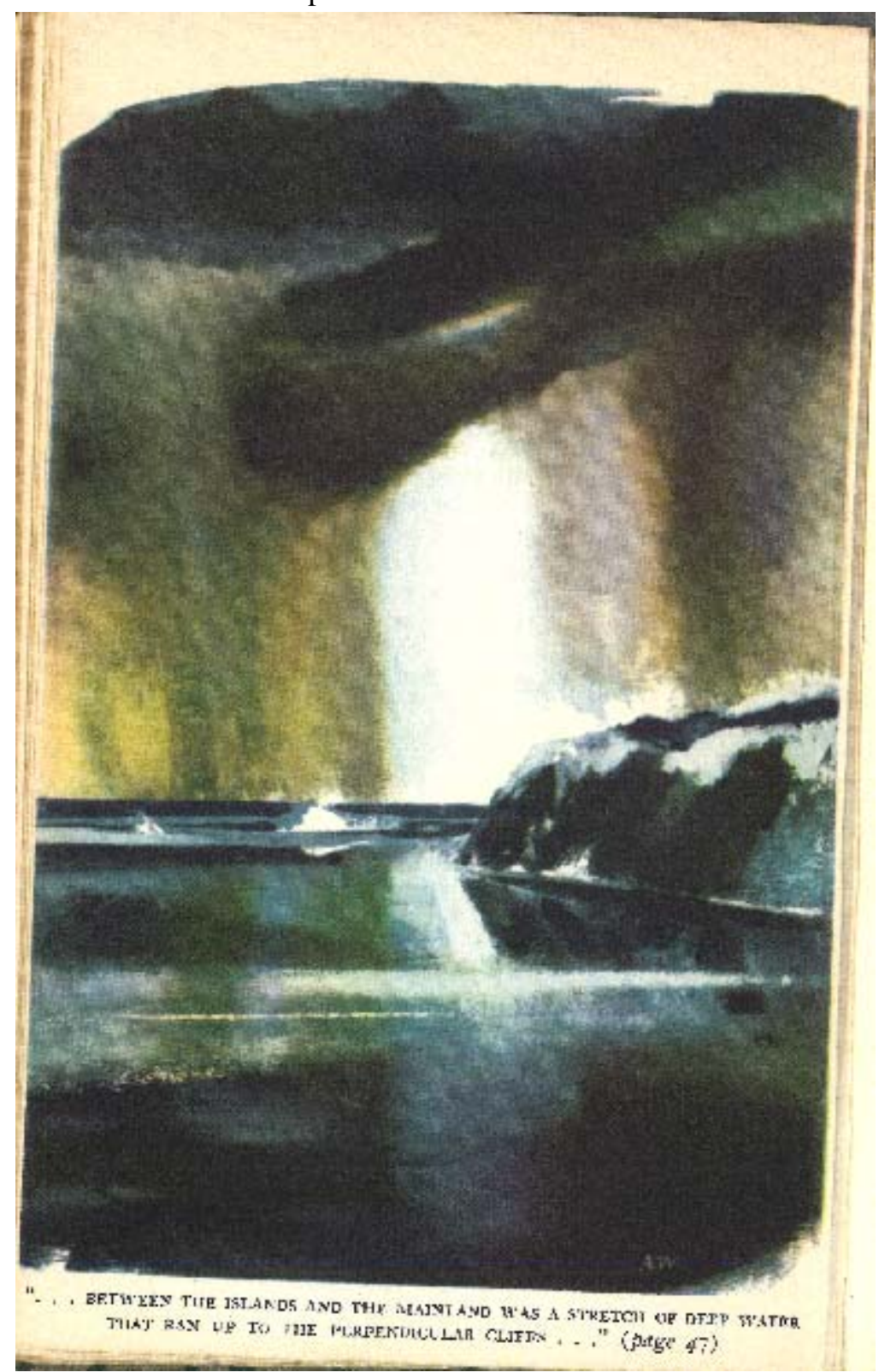

Figure 10....Between the Islands and the Mainland was a Stretch of Deep Water that Ran Up to the Perpendicular Cliffs..., 50. 
Lockwood At the world's end seals can fine peace.

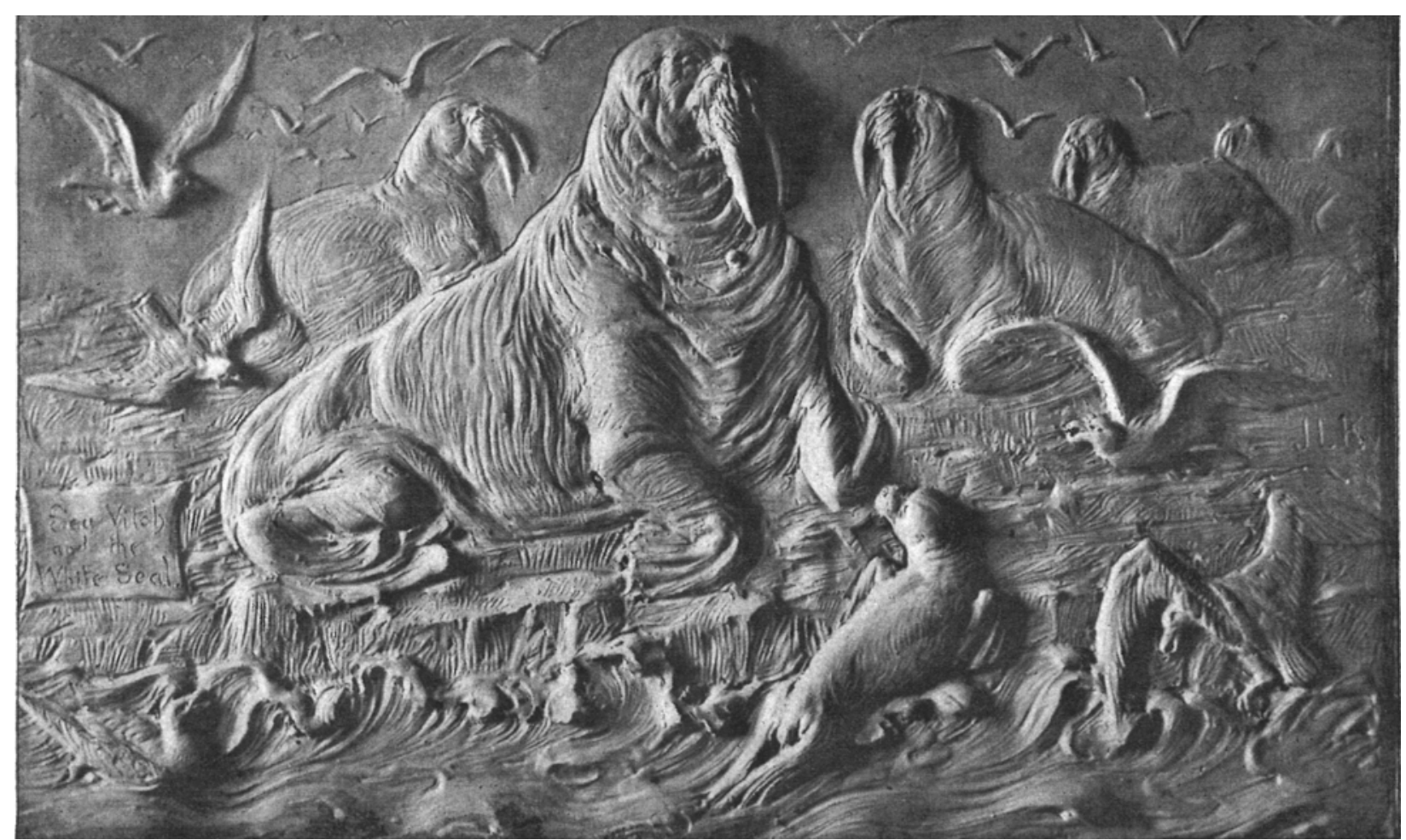

Figure 11. The White Seal, 44.

Only in the O/B edition does (2) "Toomai of the Elephants" directly follow (1) "The White Seal." Modern theorists of the ethics of the animal-human relation who favor a purer vision of animals in the wild might be horrified by this juxtaposition, since little Toomai, the story's hero, is an apprentice to his father, big Toomai, to become, like him, an elephant trainer. Little Toomai breaks with this tradition, but at a superficial level moves even closer to rejection of the wild. He rebels in such a way that he stands ready to become an elephant tracker, and to catch them in the wild forests of the Indian hills. Yet, all is not what it appears to be. It is true that much of the action takes place in the context of elephants as working animals and pets, and thus reflects Lockwood's influence rather than Seton's. ${ }^{70}$ Lockwood's comments on animal training may also have guided Rudyard. ${ }^{71}$ Yet, "Toomai” is not primarily about the elephant in civilization, but about how working and pet elephants can harken back to their wild nature - symbolized by their wild dance in the jungle. Only little Toomai is able to put himself in the position of seeing this wild dance, not just because he is on his way to becoming both superb elephant trainer in civilization and tracker in the wild, but also because he can see the limits of elephant training, and is beginning to understand the importance of empathizing with the wildness of the elephant. ${ }^{72}$ The powerful red of Watson's romantic expressionist illustration contrasts strikingly with the blue of the "White Seal" illustration. Lockwood's elephant illustration not only draws upon his written accounts of the majesty of elephants, but also with great artistry breaks out of classical forms into an almost suppressed expressionist distortion, that says: this

\footnotetext{
${ }^{70}$ Lockwood Kipling, Beast and Man in India, 207-208, 220, 224-225, 228, 238, 240, 242.

${ }^{71}$ Ibid., 302.

${ }^{72}$ Rudyard Kipling, “Toomai of the the Elephants,” 90-94.
} 
elephant is tame, but underneath he is wild. ${ }^{73}$

Watson: The elephant is triumphant.

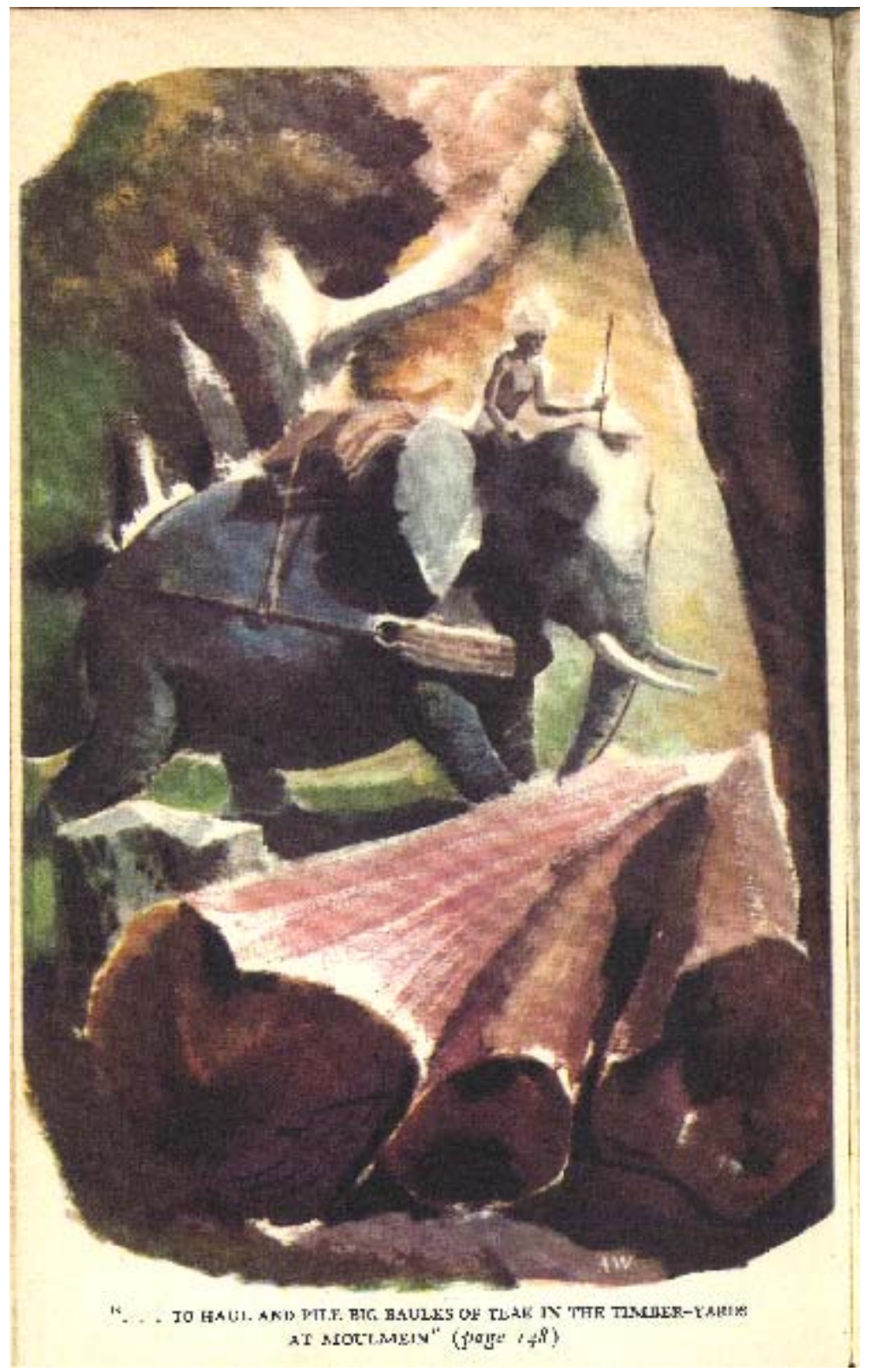

Figure 12. ...To Haul and Pile Big Baulks of Teak in the Timber-Yards at Moulmein, 174.

\footnotetext{
${ }^{73}$ Lockwood Kipling, Beast and Man in India, 57-59, 72, 74.
} 
Lockwood The elephant is triumphant.

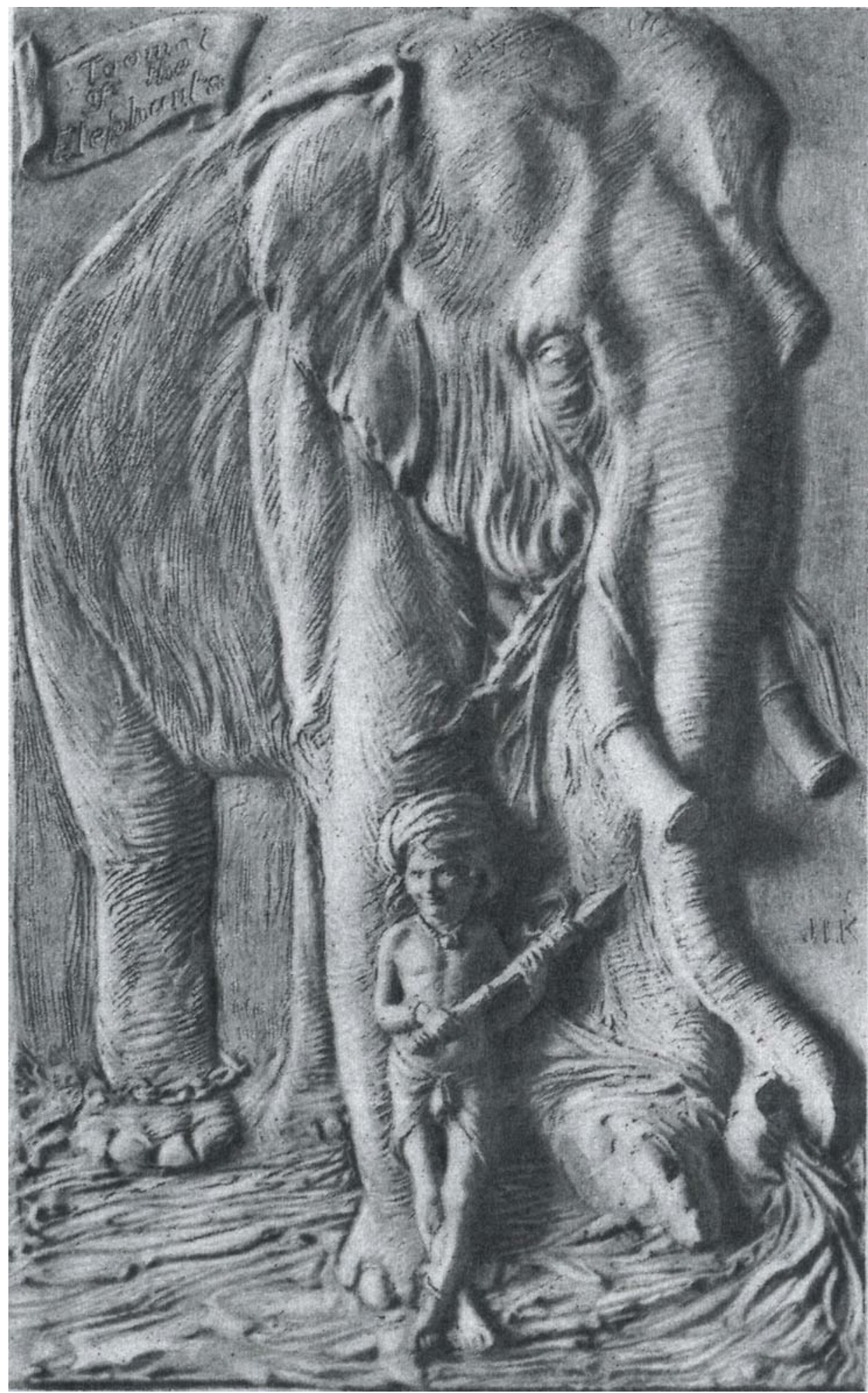

Figure 13. Toomai of the Elephants, Frontpiece. 
In (3) “The Miracle of Purun Baghat,” Purun is a Hindu former administrator and intellectual who gives it all up because he "wanted to go back to the heart of things," and "to learn and discern of his brother the clod, of his brother the brute and his brother the God." ${ }^{74}$ His pilgrimage to the heart of things and to the messages that the clod, the brute and the God bring, involves not only a Mowgli like solidarity with and mercy and empathy for animal suffering, but also a most unMowgli like adventure in which both he and the animals, based on ideals uniting clod, brute and God, show empathy for and bring mercy to a suffering village. "The Miracle of Purun Baghat” illustrates the Lockwood Kipling based Hinduism and humane society empathy theme of solidarity with the animal world, revealed by Purun's background.

Purun takes to the road as a pilgrim, and eats morsels that ordinary Indians shared with people they regarded as holy. ${ }^{75}$ He travels to the North, to the Himalayas, in the area of Simla, where he has out of the body experiences and goes to a place where nothing is big or small, back to the heart of things, where the whole soul begins. ${ }^{76}$ In the end, after the rain that almost destroys a village by causing an avalanche, and kills Purun as he and his animals warn the villagers, animals crowd around his body. ${ }^{77}$

In contrast to the blue, black and green of his "White Seal" illustration, Watson went back to the dark red and brown of the heat of his illustration of "How Fear Came" to depict in the form of alienation expresionism nature's attack on the village. Lockwood, in contrast, once again wrapped his expressionist tension beneath a classical calm as the animals surround Purun as a reward for his faith.

\footnotetext{
${ }^{74}$ Rudyard Kipling, “The Miracle of Purin Baghat,” 197.

${ }^{75}$ Ibid., 175-177.

${ }^{76}$ Ibid., 184-185, 189.

${ }^{77}$ Ibid., 194.
} 
Watson: There is fear and trembling in the hills beyond the Jungle.

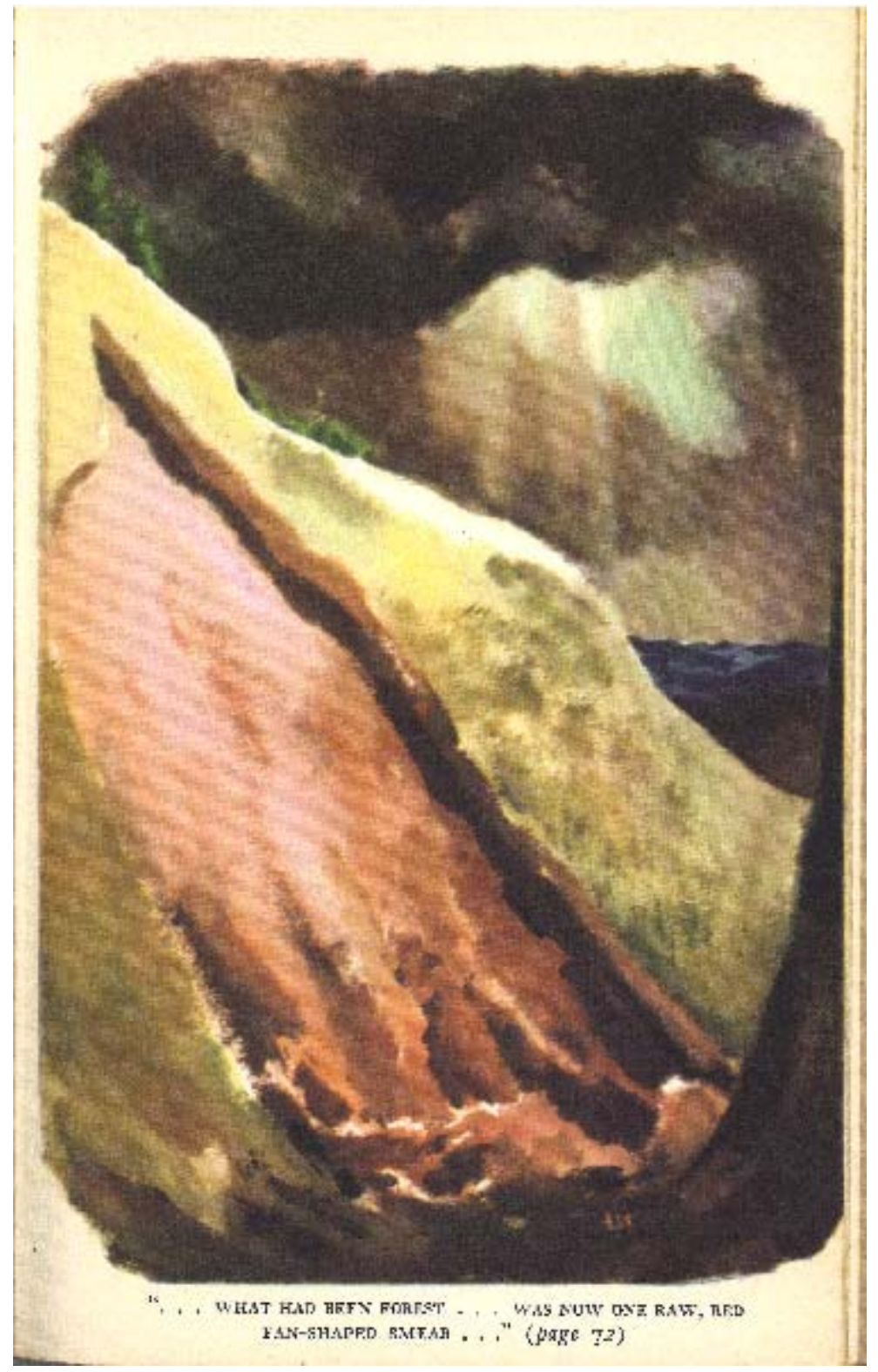

Figure 14. ... What had Been Forest ... was Now One Raw, Red Fan-Shaped Smear ..., 67. 
Lockwood in the hills beyond the jungle there is peace between humans an animals.

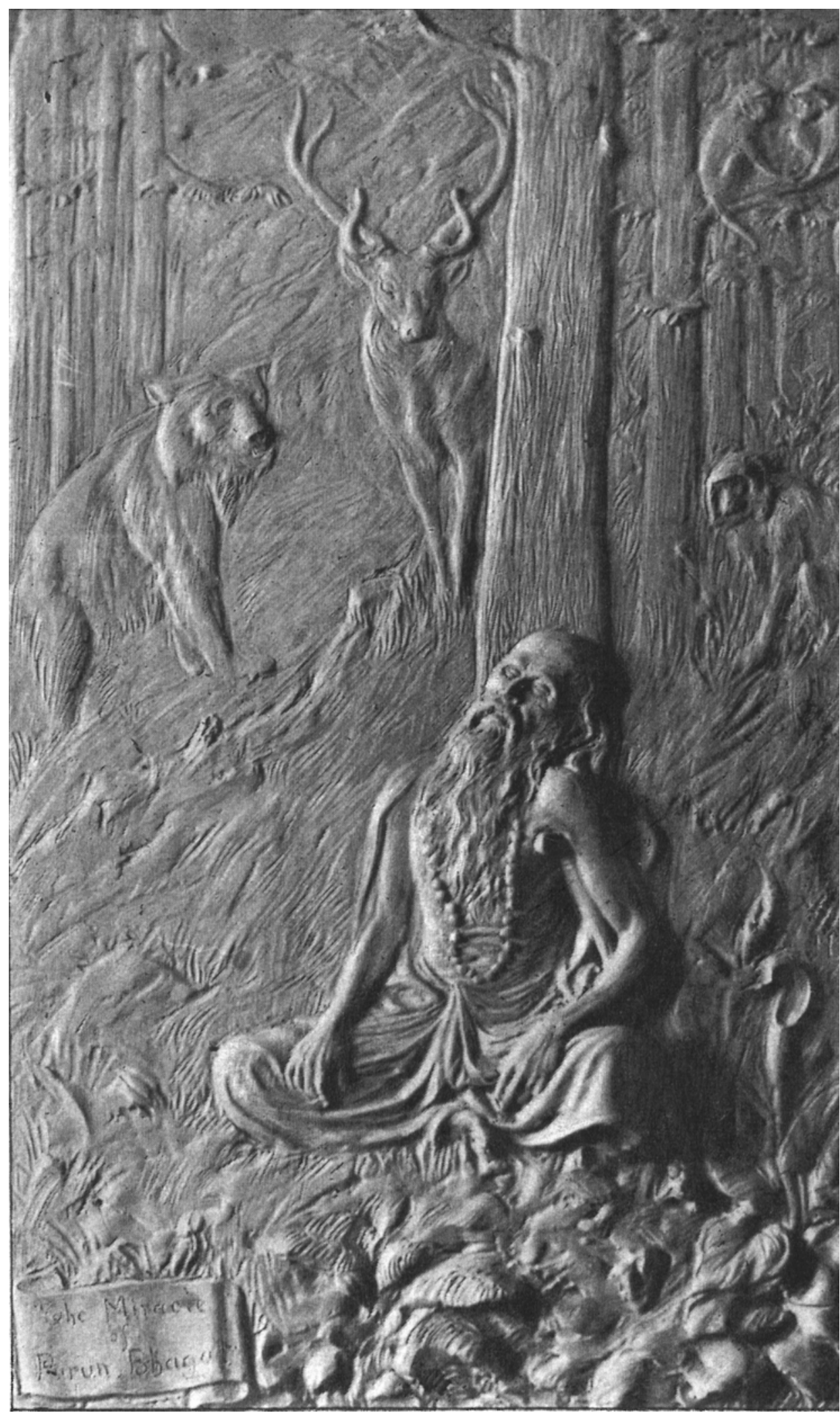

Figure 15. The Miracle of Purun Baghat, 196. 


\section{Conclusion}

Thus, Rudyard's great personal struggle was to chronicle the role of humanity on the boundaries of the animal world, and the world of civilization. In much of the Jungle Books Rudyard filtered through his artistic imagination the deep animal empathy literature available to him—-that of Lockwood and Seton—and added to it his own experience and his ability to blend fantasy and realism in an account of empathy in the animal-human relationship —in the wild and in civilization — that stands almost alone in nineteenth century literature in English. It was the great achievement of Lockwood and Watson to have expressed this vision in visual art.

\section{References}

Bushart, M. (1995). Chagging Times, Changing Styles: Wilhelm Worringer and the Art of His Epoch. In N. Donahue (Ed.), Invisible shadows the expressionist art history of Wilhelm Worringer. University Park, Pennsylvania: Pennsylvania State University Press.

Dobrée, B. (1967). Rudyard Kipling Realist and Fantasist. Oxford: Oxford University Press.

Fischer, N. (1996). From Aesthetic Education to Environmental Aesthetics. Clio, 25(4), 365-391.

Fischer, N. (2011). Rudyard Kipling’s Stories of Overcoming Existential Angst Through Empathy. Janus Head, 12(2), $259-268$.

Fischer, N. (2013). Empathy in Kipling’s Stories of Humans and Dogs. The Kipling Journal, 87(4), 32-42.

Kierkegaard, S. (1954). Fear and Trembling and the Sickness Unto Death. New York: Doubleday/Anchor.

Kipling, J. L. (1891). Beast and Man in India. London: Macmillian.

Kipling, R. (1888). The Phantom Rickshaw and other eerie tales. London: A. H. Wheeler and Co., Indian Railway Library.

Kipling, R. (1894). The Jungle Book. London: Macmillan.

Kipling, R. (1895). The Second Jungle Book. London: Macmillan.

Kipling, R. (1897a). The Strange Ride of Mowbay Jukes, The Man Who Would be King. The Phantom Rickshaw and other stories. New York: Charles Scribners Sons.

Kipling, R. (1897b). The Writings in Prose and Verse of Rudyard Kipling. The Jungle Book (Vol. VII); The Second Jungle Book, (Vol.VIII). New York: Charles Scribner Sons.

Kipling, R. (1937). Something of Myself. London: Macmillan..

Kipling, R. (1948). The Jungle Books (Vol. I and II, illustrated by by Aldren Watson, “Forward” by Nelson Doubleday). New York: Doubleday.

Naess, A. (1985) Identification as a Source for Deep Ecological Attitudes. In M. Tobias (Ed.), Deep Ecology. San Diego: Avanti Books.

Naess, A. (1990). Man Apart and Deep Ecology: A reply to Reed. Environmental Ethics, 190-191.

Naess, A. (1995). The Deep Ecology Movement Some Philosophical Aspects; Self-Realization. Deep Ecology for the 21st Century. New York : Shambala.

Read, H. (1957). Introduction, Wilhelm Worringer. Form in Gothic. New York: Schocken.

Read, H. (1967). Art and Alienation. New York: Viking.

Read, H. (1977). The Philosophy of Modern Art. London: Faber and Faber.

Reed, P. (1989). Not Man Apart: An Alternative to the Self-realization Approach. Environmental Ethics, 11(1), 53-69

Riegl, A. (1991). Spăatromische Kunstindustrie. Vienna: Vero.

Thompson, E. S. (1894). The king of currumpaw, a wolf story. Scribners Magazine, November.

Thompson, E. S. (1898). Wild animals $i$ have known. York: Charles Scribners Sons.

Seton, E. T. (1940). The trail of an artist-naturalist. New York: Charles Scribners Sons.

Witt, D. L. (2010). Ernest Thompson Seton: The Life and Legacy of An Artist and Conservationist. Salt Lake City: Gibbs Smith.

Wolfflin, H. (1952). Principles of art history. New York: Dover.

Worringer, W. (1910). Formproblem der Gothik. Munich: Piprt.

Worringer, W. (1957) Form in Gothic, with an Introduction by Herbert Read. New York: Schocken.

Worringer, W. (1959). Abstraaktion und Einfuhlung. mit ein Vorwort zur Neue Ausgabe Munich: Piper.

Zapfe, P. W. (1993). The Last Messiah. In P. Reed and D. Rothenberg, (Eds.), Wisom in the Open Air. Minneapolis: Univerity of Mennesota Press. 